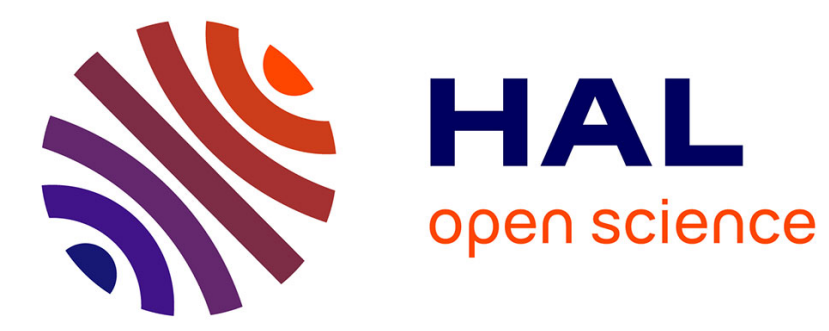

\title{
Mercury isotopes of key tissues document mercury metabolic processes in seabirds
}

\author{
Marina Renedo, Zoyne Pedrero, David Amouroux, Yves Cherel, Paco
}

Bustamante

\section{- To cite this version:}

Marina Renedo, Zoyne Pedrero, David Amouroux, Yves Cherel, Paco Bustamante. Mercury isotopes of key tissues document mercury metabolic processes in seabirds. Chemosphere, 2021, 263, pp.127777. 10.1016/j.chemosphere.2020.127777 . hal-02910894

\section{HAL Id: hal-02910894 \\ https://hal.science/hal-02910894}

Submitted on 16 Sep 2020

HAL is a multi-disciplinary open access archive for the deposit and dissemination of scientific research documents, whether they are published or not. The documents may come from teaching and research institutions in France or abroad, or from public or private research centers.
L'archive ouverte pluridisciplinaire HAL, est destinée au dépôt et à la diffusion de documents scientifiques de niveau recherche, publiés ou non, émanant des établissements d'enseignement et de recherche français ou étrangers, des laboratoires publics ou privés. 


\section{Mercury isotopes of key tissues document mercury metabolic processes in seabirds}

$\underline{\text { Marina Renedo }}{ }^{1,2^{*}}$, Zoyne Pedrero ${ }^{2 *}$, David Amouroux ${ }^{2}$, Yves Cherel $^{3}$, Paco Bustamante $e^{1,4}$

${ }^{1}$ Littoral Environnement et Sociétés (LIENSs), UMR 7266 CNRS- La Rochelle Université, 2 rue Olympe de Gouges, 17000 La Rochelle, France

${ }^{2}$ Universite de Pau et des Pays de 1'Adour, E2S UPPA, CNRS, IPREM, Institut des Sciences Analytiques et de Physico-chimie pour l'Environnement et les matériaux, Pau, France

${ }^{3}$ Centre d'Etudes Biologiques de Chizé, UMR 7372 du CNRS-La Rochelle Université, 79360 Villiers-en-Bois, France

${ }^{4}$ Institut Universitaire de France (IUF), 1 rue Descartes 75005 Paris, France

ORCID numbers: 0000-0002-9224-8745 (M. Renedo), 0000-0001-6226-152X (Z. Pedrero), 0000-0002-0056-8590 (D. Amouroux), 0000-0001-9469-9489 (Y. Cherel), 0000-0003-3877-9390 (P. Bustamante),

*Corresponding authors: marina.renedo@ird.fr; zoyne.pedrerozayas@univ-pau.fr

Keywords: methylmercury, metabolism, detoxification, demethylation, moult 


\section{Abstract}

Seabirds accumulate significant amounts of mercury $(\mathrm{Hg})$ due to their long-life span together with their medium to high trophic position in marine food webs. $\mathrm{Hg}$ speciation and $\mathrm{Hg}$ isotopic analyses of total $\mathrm{Hg}$ in different tissues (pectoral muscles, liver, brain, kidneys, blood and feathers) were assessed to investigate their detoxification mechanisms. Three species with contrasted ecological characteristics were studied: the Antarctic prion (zooplankton feeder), the white-chinned petrel (pelagic generalist consumer) and the southern giant petrel (scavenger on seabirds and marine mammals). The difference of mass-dependent fractionation (MDF, $\delta^{202} \mathrm{Hg}$ ) values between livers and muscles (up to $0.94 \%$ ) in all three seabirds strongly suggests hepatic methylmercury $(\mathrm{MeHg})$ demethylation and redistribution of the isotopically heavier fraction of $\mathrm{MeHg}$ towards the muscles. Similarly, higher $\delta^{202} \mathrm{Hg}$ values in feathers (up to $1.88 \%$ ) relative to muscles and higher proportion of $\mathrm{MeHg}$ in feathers (94-97\%) than muscles (30-70\%) likely indicate potential $\mathrm{MeHg}$ demethylation in muscle and preferential excretion of $\mathrm{MeHg}$ (isotopically heavier) in the growing feathers during moult. The extents of these key detoxification processes were strongly dependent on the species-specific detoxification strategies and levels of dietary $\mathrm{MeHg}$ exposure. We also found higher mass-independent fractionation (MIF, $\Delta^{199} \mathrm{Hg}$ ) values in feathers relative to internal tissues, possibly due to different integration times of $\mathrm{Hg}$ exposure between permanently active organs and inert tissues as feathers. $\mathrm{Hg}$ isotope variations reported in this study show evidence of detoxification processes in seabirds and propose a powerful approach for deep investigation of the $\mathrm{Hg}$ metabolic processes in seabirds. 


\section{Introduction}

Mercury (Hg) presents several adverse effects for the health of humans and wildlife. In predators, the main exposure pathway to $\mathrm{Hg}$ is the consumption of prey containing methylmercury ( $\mathrm{MeHg}$ ), a bioaccumulative neurotoxin that biomagnifies in food webs. In seabirds, $\mathrm{Hg}$ toxicity affects their behaviour, physiology and development (Evers et al., 2008; Tan et al., 2009), with serious consequences at the population level (Goutte et al., 2014a, 2014b).

Once ingested, MeHg is efficiently absorbed and transported through the blood to internal tissues, where it is stored, demethylated or excreted. Hepatic demethylation of MeHg into less toxic inorganic $\mathrm{Hg}(\mathrm{Hg}(\mathrm{II}))$ appears to be a major detoxification mechanism in seabirds (Thompson and Furness, 1989a; Thompson et al., 1993; Kim et al., 1996). Hg accumulates significantly as an inert $\mathrm{Hg}$-selenium (Se) complex called tiemannite in the liver of seabirds (Arai et al., 2004; Ikemoto et al., 2004), thus reducing its bioavailability and impeding its remobilisation (Cuvin-Aralar and Furness, 1991). The presence of HgSe complexes had also been identified in the liver of marine mammals (Koeman et al., 1973; Martoja, 1980; Palmisano et al., 1995; Gajdosechova et al., 2016). Previous studies also reported the presence of metallothioneins, which are cysteine-rich proteins with high affinity to $\mathrm{Hg}(\mathrm{II})$ (and other trace elements, such as $\mathrm{Cd}$ or $\mathrm{Zn}$ ) in tissues of seabirds (Elliott et al., 1992; Andrews et al., 1996; Elliott and Scheuhammer, 1997; Arai et al., 2004; Braune and Scheuhammer, 2008). The correlation between metallothionein and $\mathrm{Hg}(\mathrm{II})$ concentrations in the liver of seabirds could suggest an important role of these proteins in their $\mathrm{Hg}$ detoxification processes (Kojadinovic et al., 2007; Kehrig et al., 2015), as it seems to occur in dolphin livers (Das et al., 2002; Pedrero et al., 2012). Gradual decrease of $\mathrm{Hg}$ concentrations in seabird internal tissues during feather moult was identified as 
remobilisation of $\mathrm{Hg}$ body burden into growing feathers, leading to the elimination of up to $80 \%$ of the total accumulated $\mathrm{Hg}$ (Furness et al., 1986; Honda et al., 1986; Braune, 1987). Since relatively high $\mathrm{Hg}$ concentrations (almost exclusively $\mathrm{MeHg}$ ) are usually measured in feathers (Renedo et al., 2017), the feather moult is considered as the main route for MeHg elimination in seabirds (Thompson and Furness, 1989a; Thompson et al., 1990). However, the evidence of excretion of $\mathrm{MeHg}$ by feathers is based simply on the balance of $\mathrm{Hg}$ concentrations between feathers and internal tissues, while the relative importance of the different soft tissues in the storage and distribution of $\mathrm{Hg}$ is not known. Feathers are then considered as archives of $\mathrm{MeHg}$ exposure since the previous feather synthesis (Monteiro et al., 1996). However, depending on the species, feathers can reflect the $\mathrm{MeHg}$ that has been accumulated in internal tissues between two successive moults (capital strategy) or the recent $\mathrm{MeHg}$ intake (income strategy) (Cherel et al., 2018).-

Understanding $\mathrm{Hg}$ bioaccumulation, inter-tissue redistribution and detoxification or excretion processes in seabirds represents a great challenge. In the last decades, numerous studies investigated $\mathrm{Hg}$ levels and speciation in internal tissues focusing on the toxicokinetics (Bearhop et al., 2000; Spalding et al., 2000; Monteiro and Furness, 2001) or on their use as bioindicators of Hg contamination (Norheim and Frøslle, 1978; Dietz et al., 1990; Kim et al., 1996; Kehrig et al., 2015). So far, the investigation of internal redistribution processes of $\mathrm{Hg}$ in seabirds is only based on inter-organ variations of $\mathrm{Hg}$ levels so all these metabolic aspects have never been extensively studied.

The measurement of $\mathrm{Hg}$ isotopic composition in biological samples is widely applied for tracing $\mathrm{Hg}$ trophic sources and metabolic response in biota (Feng et al., 2015; Perrot et al., 2016; Bolea-Fernandez et al., 2019; Li et al., 2016; 2020). Hg stable isotopes can undergo both mass-dependent fractionation (MDF, $\delta^{202} \mathrm{Hg}$ ) and mass-independent 
fractionation (MIF), mainly involving $\mathrm{Hg}$ odd isotopes in biota $\left(\Delta^{199} \mathrm{Hg}\right.$ and $\left.\Delta^{201} \mathrm{Hg}\right) . \mathrm{Hg}$ MDF has been reported during in vivo $\mathrm{Hg}$ reduction and methylation/demethylation processes since lighter isotopes of $\mathrm{Hg}$ react preferentially (Kritee et al., 2007, 2009; Rodriguez Gonzalez et al., 2009). Metabolic processes such as Hg species-specific accumulation in target organs, inter-tissue transport or $\mathrm{Hg}$ detoxification mechanisms involve $\mathrm{Hg} \mathrm{MDF}$, which has been widely used as a proxy of internal processes in aquatic organisms such as fish (Kwon et al., 2013a; Feng et al., 2015; Rua-Ibarz et al., 2019) and marine mammals (Perrot et al., 2016; Masbou et al., 2018; Bolea-Fernandez et al., 2019; Li et al., 2020). Significant MIF of $\mathrm{Hg}$ odd isotopes $\left({ }^{199} \mathrm{Hg}\right.$ and ${ }^{201} \mathrm{Hg}$ ) has only been observed during $\mathrm{Hg}$ photochemical processes (Bergquist and Blum, 2007), therefore positive odd-MIF values are typically observed in aquatic organisms due to photochemical degradation of $\mathrm{MeHg}$ in the photic zone of the water column (Bergquist and Blum, 2007; Senn et al., 2010; Point et al., 2011; Day et al., 2012; Perrot et al., 2012). However, $\mathrm{Hg}$ odd-MIF is not induced by biological or trophic processes (Kritee et al., 2007, 2009; Kwon et al., 2013; Feng et al., 2015); so this isotopic signature is conserved during trophic transfer of $\mathrm{MeHg}$ and used as a proxy of $\mathrm{Hg}$ sources before assimilation into the food webs. Thus, the exploration of $\mathrm{Hg}$ MIF signatures on migratory seabirds can provide interesting information about $\mathrm{MeHg}$ trophic sources of the oceanic compartments at large scale. Besides, depending on the tissue-specific integration times of $\mathrm{Hg}, \mathrm{Hg} \mathrm{MIF}$ signatures can give access to specific temporal scales of seabird $\mathrm{Hg}$ exposure.

In this study, we present $\mathrm{Hg}$ speciation and $\mathrm{Hg}$ isotopic composition of feathers and several internal tissues (pectoral muscles, liver, brain, kidneys and blood) of three seabird species with contrasting feeding ecologies. Our objective is to explore the $\mathrm{Hg}$ 
transformations and biological fate of $\mathrm{Hg}$ and to find evidence of seabird detoxification strategies face to $\mathrm{Hg}$ exposure.

\section{Materials and Methods}

\subsection{Ecological characteristics of the studied seabirds}

The Antarctic prion (Pachyptila desolata) is a small burrowing petrel that moves far from the colonies between breeding periods (mainly to subtropical waters) and returns to the Southern Ocean to breed (Cherel et al., 2016). It is a surface-feeder that preys upon swarming crustaceans, mainly the hyperiid Themisto gaudichaudii and the subantarctic krill Euphausia vallentini to feed its single chick (Cherel et al., 2002). In Kerguelen Islands, adults forage from subantarctic to Antarctic waters during the chick-rearing period (Cherel et al., 2002).

The white-chinned petrel (Procellaria aequinoctialis) is a large burrowing petrel and one of the most abundant seabirds in the Southern Ocean. It mainly feeds by surface-seizing but is also an efficient diver (Rollinson et al., 2014). In Kerguelen Islands, the chick diet is mostly composed of fish, but it also includes crustaceans, cephalopods, and offal and discards from fishing vessels (Delord et al., 2010). During the chick rearing period, seabirds from the Kerguelen Islands forage from subantarctic to Antarctic waters (Delord et al., 2010), and they winter in the Benguela Current where they feed primarily on fish and offal (Jackson, 1988; Péron et al., 2010).

Together with the closely related northern giant petrel (Macronectes halli), the southern giant petrel (M. giganteus) is the largest petrel and the dominant scavenger in the Southern Ocean (González-Solís, 2002). During the breeding period, the species presents sexrelated foraging strategies, with males mainly scavenging on land and females primarily 
feeding at sea (Thiers et al., 2014). During the inter-breeding periods, both males and females are pelagic within the southern Indian Ocean (Thiers et al., 2014). As the whitechinned petrel, giant petrels are ship-followers, being thus at risk to be killed by fishing gears.

\subsection{Sample collection}

Ten freshly dead individuals of Antarctic prions trapped in the vegetation (Fromant et al., 2016) and of white-chinned petrels killed on longlines were collected at the Kerguelen archipelago $\left(49^{\circ} 21^{\prime} \mathrm{S}, 70^{\circ} 18^{\prime} \mathrm{E}\right)$ in January 2012 and October 2003, respectively. Loss of labels precludes precise knowledge of both origins and sampling dates of southern giant petrels $(n=3)$, however seabirds were collected dead either at Crozet Islands (subantarctic waters) and/or in Adélie Land (high Antarctica). The internal tissues analysed in this study were sampled, weighed and stored individually in plastic bags. Blood samples were obtained by collecting clotted blood from heart atria and stored in Eppendorf microtubes. We collected pectoral muscles and liver from white-chinned petrels $(n=10)$. For Antarctic prions $(\mathrm{n}=10)$, we collected pectoral muscles, liver, kidneys, and blood samples. For southern giant petrels $(n=3)$, we extracted pectoral muscles, livers, brains, kidneys, and blood samples $(n=3)$. We could not collect the liver of the southern giant petrel number 2 due to the partial lack of internal organs in that specimens. After dissection, all the samples were stored at $-20^{\circ} \mathrm{C}$. Prior to the analyses, internal tissues were cryogenically powdered and freeze-dried. Body feathers were removed from the breast of Antarctic prions and southern giant petrels and stored dry. Flying feathers from white-chinned petrels were collected. Feathers were cleaned in a 2:1 chloroform/methanol mixture, oven-dried and homogenised as detailed in Carravieri et al. (2013). 
The internal tissues and feathers collected from the three seabird species were analysed for $\mathrm{THg}$ concentrations, $\mathrm{Hg}$ speciation and $\mathrm{Hg}$ isotopic composition. Only blood and kidney samples from Antarctic prions could not be analysed for $\mathrm{Hg}$ isotopic composition due to low sample amounts.

\subsection{Analytical techniques}

\subsubsection{Hg speciation analysis}

Samples were digested by microwave-assisted extraction using a CEM microwave system (Discover SP-D, CEM Corporation) coupled to an autosampler Explorer 487296 (USA). The extraction was carried out in CEM Pyrex vessels by 1 min of warming up to $75^{\circ} \mathrm{C}$ and 3 min at $75^{\circ} \mathrm{C}$ with magnetic agitation to homogenise the samples. Feathers $(\sim 100$ mg dry weight $(\mathrm{dw}))$ were digested using nitric acid $\left(\mathrm{HNO}_{3} \cdot 6 \mathrm{~N}\right.$, INSTRA quality) with addition of isotopic enriched standard solutions before the extraction process following Renedo et al. (2017). Blood and internal tissues (100-150 mg dw) were digested with 5 $\mathrm{mL}$ of tetramethylammonium hydroxide (25\% TMAH in $\mathrm{H}_{2} \mathrm{O}$, Sigma Aldrich). Quantification of $\mathrm{Hg}$ species was carried out by isotope dilution analysis, using a GCICP-MS Trace Ultra GC equipped with a Triplus RSH autosampler coupled to an ICPMS XSeries II (Thermo Scientific, USA) as detailed elsewhere (Clémens et al., 2011). Total $\mathrm{Hg}$ concentrations ( $\mathrm{THg}$ ) were also quantified by using an advanced $\mathrm{Hg}$ analyser spectrophotometer (AMA-254, Altec) for method intercomparison and corroboration of $\mathrm{THg}$ concentrations obtained by $\mathrm{Hg}$ speciation analyses. We also performed $\mathrm{Hg}$ speciation analyses of certified reference materials (CRM) for QA/QC purposes (Table S1). 
Three CRMs with certified concentration values of both $\mathrm{THg}$ and $\mathrm{MeHg}$, were used in this study for THg, speciation and of isotopic analyses: NIES-13 (human hair), DOLT-4 (dogfish liver) and ERM-CE-464 (tuna fish). An additional CRM, i.e., human hair IAEA086, was also used for $\mathrm{Hg}$ isotopic analyses. King penguin feather and red blood cells samples (F-KP and RBC-KP, respectively) were used as internal reference materials.

\subsection{2 $\mathrm{Hg}$ isotopic composition analysis}

Amounts of 100-150 mg of sample (dw) were digested with $5 \mathrm{~mL}$ of $\mathrm{HNO}_{3}$ acid $(65 \%$, INSTRA quality) after a predigestion step overnight at room temperature. Feathers and blood samples were digested in Savillex vessels at $75^{\circ} \mathrm{C}$ during $8 \mathrm{~h}$ in a Hotblock $(6 \mathrm{~h}$ in $\mathrm{HNO}_{3}$ and then $2 \mathrm{~h}$ after the addition of $1.66 \mathrm{~mL}$ of $\mathrm{H}_{2} \mathrm{O}_{2}, 30 \%$ ULTREX quality). Internal tissues (muscle, liver, kidney and brain) were digested in a High Pressure Asher (HPA) mineralisation system at high conditions of pressure (130 bar) and temperature (temperature ramp: $\left.80^{\circ} \mathrm{C}-120^{\circ} \mathrm{C}\left(2^{\circ} \mathrm{C} / \mathrm{min}\right)-300^{\circ} \mathrm{C}(2.5 \mathrm{~h})-80^{\circ} \mathrm{C}(1 \mathrm{~h})\right) . \mathrm{Hg}$ isotopic composition was determined for the six most abundant stable $\mathrm{Hg}$ isotopes $\left({ }^{198} \mathrm{Hg},{ }^{199} \mathrm{Hg}\right.$, ${ }^{200} \mathrm{Hg},{ }^{201} \mathrm{Hg},{ }^{202} \mathrm{Hg}$ and ${ }^{204} \mathrm{Hg}$ ) using a cold-vapour generator (CVG)-multicollector (MC)-ICPMS (Nu Instruments), following (Renedo et al., 2018a). Hg isotopic values were reported as delta notation, calculated relative to the bracketing standard NIST SRM3133 CRM to allow inter-laboratory comparisons. NIST SRM-997 thallium standard solution was used for the instrumental mass-bias correction using the exponential law (details in SI). Recoveries of $\mathrm{Hg}$ extraction (acid digestion) were verified for all samples by checking the signal intensity obtained on the MC-ICPMS for diluted extracts relative to NIST 3133 standard (with an approximate uncertainty of $\pm 15 \%$ ) (Blum and Bergquist, 2007). THg concentrations in the extract solution were compared to the concentrations 
found by AMA-254 analyses to assess method recovery. Uncertainty for delta values was calculated using 2SD typical errors for each internal reference material (Table S2).

\section{$2.4 \quad$ Statistical tests}

Statistical analyses were performed using R 3.3.2 (R Core Team, 2016). Before analyses, data were checked for normality of distribution and homogeneity of variances using Shapiro-Wilk and Breusch-Pagan tests, respectively. According to this, parametrical (One-way ANOVA) or non-parametrical tests (Kruskal-Wallis with Conover-Iman test) were performed. Statistically significant results were set at $\alpha=0.05$. We examined the correlations between $\mathrm{Hg}$ concentrations, $\mathrm{Hg}$ speciation, $\mathrm{Hg} \mathrm{MDF}\left(\delta^{202} \mathrm{Hg}\right)$ and odd-MIF $\left(\Delta^{199} \mathrm{Hg}\right)$ using linear regressions and Spearman correlation rank tests.

\section{Results and discussion}

3.1 Tissue-specific $\mathrm{Hg}$ levels, speciation and $\mathrm{Hg}$ isotopic composition related to distinct $\underline{\text { metabolic processes }}$

$\mathrm{Hg}$ internal dynamics in seabirds are highly complex and potentially variable between species according to their specific detoxification rates and strategies face to $\mathrm{Hg}$ levels of exposure. The high variability of $\mathrm{Hg}$ levels in the tissues observed between the three seabird species considered in this study (Fig. 1) supports the existence of distinct extent of $\mathrm{Hg}$ detoxification mechanisms among species. The degree of exposure to $\mathrm{Hg}$, their moult frequency and the efficiency of $\mathrm{Hg}$ excretion by moulting are known to strongly influence their detoxification strategies (Bearhop et al., 2000).

Antarctic prions exhibited similar mean THg levels in feathers and liver $(2.6 \pm 0.9$ and $2.1 \pm 0.5 \mu \mathrm{g} \cdot \mathrm{g}^{-1}$, respectively), whereas lower concentrations were detected in kidneys, blood and muscle $\left(0.9 \pm 0.2,0.7 \pm 0.1\right.$ and $0.3 \pm 0.1 \mu \mathrm{g} \cdot \mathrm{g}^{-1}$, respectively $)(\mathrm{H}=42.79, \mathrm{p}<$ 
0.0001) (Table S3). White-chinned petrels showed higher mean THg concentrations in the liver $\left(54.3 \pm 18.7 \mu \mathrm{g} \cdot \mathrm{g}^{1}\right)$ compared to muscles and feathers $(4.7 \pm 1.8$ and $5.4 \pm 2.2$ $\mu \mathrm{g} \cdot \mathrm{g}^{-1}$, respectively) $(\mathrm{H}=19.355, \mathrm{p}<0.0001)$ (Table $\left.\mathrm{S} 4\right)$. In the case of giant petrels $(\mathrm{n}=3)$, Hg concentrations were highly variable likely due to age differences among individuals. Liver was also the most highly concentrated organ, with concentrations of 405 and 214 $\mu \mathrm{g} \cdot \mathrm{g}^{-1}$ for the two analysed individuals (old and young, respectively). As previously explained, the liver of the medium-age giant petrel could not be dissected. Kidneys of giant petrels were also highly concentrated, ranging from 27.5 to $50.8 \mu \mathrm{g} \cdot \mathrm{g}^{-1}$ between individuals (Table S5).

$\mathrm{Hg}$ species proportion was variable depending on the tissue considered, with $\mathrm{THg}$ being almost $100 \% \mathrm{MeHg}$ in feathers and from 2 to $74 \% \mathrm{MeHg}$ in the liver (Fig. 1). This high inter-species variability confirms a strong influence of their contrasted $\mathrm{Hg}$ exposure due to different foraging habits and trophic levels, and consequently to species-specific variations in $\mathrm{Hg}$ detoxification mechanisms (Carravieri et al., 2014; Cipro et al., 2014; Fromant et al., 2016). High proportions of $\mathrm{MeHg}$ in feathers, blood and muscles are commonly observed in seabirds (Thompson and Furness, 1989b; Kim et al., 1996; Kim et al., 1998; Scheuhammer et al., 1998). Although in lower percentages, MeHg also predominated in the liver of Antarctic prions (mean $66 \pm 6 \%$, up to $74 \%$ ), likely because $\mathrm{Hg}$ exposure is low in this zooplanktivorous species. In contrast, hepatic $\mathrm{Hg}$ was almost exclusively $\mathrm{Hg}$ (II) (84 - 98\%) for both white-chinned and giant petrels, likely as a consequence of their high $\mathrm{Hg}$ exposure inducing $\mathrm{MeHg}$ demethylation (see below next section). 


\subsection{Hg MDF: Implications for Hg detoxification strategies in seabird species}

\subsubsection{Evidence of $\mathrm{MeHg}$ demethylation in liver}

Tissue-specific $\delta^{202} \mathrm{Hg}$ values for $\mathrm{THg}$ were significantly correlated to the respective percentage of $\mathrm{MeHg}$ in tissues of the three seabird species (Fig. 2). Antarctic prions exhibited lower $\delta^{202} \mathrm{Hg}$ values in the liver $(0.01 \pm 0.25 \%)$ than in tissues with higher proportion of $\mathrm{MeHg}$, such as muscles $(0.37 \pm 0.41 \%)$ and feathers $(1.32 \pm 0.13 \%$ ) $(\mathrm{H}=18.10, \mathrm{p}<0.0001)$ (Table S3). The same pattern was observed for white-chinned petrels, for which liver exhibited low mean $\delta^{202} \mathrm{Hg}$ values $(-0.64 \pm 0.27 \%$ ) and muscles and feathers presented positive $\delta^{202} \mathrm{Hg}$ signatures $(0.30 \pm 0.28 \%$ and $1.10 \pm 0.14 \%$, respectively) $(\mathrm{H}=25.30, \mathrm{p}<0.0001)$ (Table $\mathrm{S} 4)$. Giant petrels also exhibited significantly higher $\delta^{202} \mathrm{Hg}$ values in feathers (2.32 to $2.35 \%$ ) however, the trend of $\delta^{202} \mathrm{Hg}$ values in their liver and muscles were highly variable depending on the individual, possibly due to age differences reflecting different extent of $\mathrm{Hg}$ bioaccumulation (Table S3). As observed for Antarctic prions and white-chinned petrels, the young giant petrel exhibited lower $\delta^{202} \mathrm{Hg}$ values in liver $(-0.28 \%$ o $)$ than in muscle $(0.38 \%$ o $)$. However, the old individual presented the opposite trend with higher $\delta^{202} \mathrm{Hg}$ values in liver $(0.68 \%$ ) than in muscle $(0.55 \%$ ). This finding could be mostly explained by the low proportion of $\mathrm{MeHg}$ in the muscle of the old individual (37\%) compared to the other seabirds analysed (normally varying between 50-90\%). Indeed, the trends observed in the three seabird species indicate a compound-specificity of the $\mathrm{Hg}$ isotopic signatures, i.e., different $\mathrm{Hg}$ isotopic compositions of $\mathrm{MeHg}$ and $\mathrm{Hg}$ (II) among tissues and the proportion of the total $\mathrm{Hg}$ isotopic composition according to the specific $\mathrm{Hg}$ species distribution of each tissue (Fig $\mathrm{S} 1$ ). This observation strongly suggests the occurrence of $\mathrm{Hg}$ transformations or specific 
distribution mechanisms between $\mathrm{Hg}$ species that induce an isotopic fractionation (i.e. hepatic demethylation, inter-tissue redistribution).

The significant difference of $\delta^{202} \mathrm{Hg}$ values between the liver and the muscles of Antarctic prions $(\sim 0.36 \%)$ and white-chinned petrels $(\sim 0.94 \%$ ), together with the relatively lower proportion of $\mathrm{MeHg}$ in their liver, suggest that hepatic $\mathrm{Hg}$ demethylation does occur in these-seabird species. After in vivo hepatic demethylation, the produced $\mathrm{Hg}(\mathrm{II})$ and the residual $\mathrm{MeHg}$ might be redistributed to different tissues, where they are likely complexed by specific ligands (Bridges and Zalups, 2010; Pedrero et al., 2012; Perrot et al., 2016). Among these ligands, the strong affinity of MeHg for sulphydryl groups of proteins leads to a preferential redistribution towards the muscles. Liver is assumed to mainly accumulate $\mathrm{Hg}(\mathrm{II})$, partially sequestered as insoluble $\mathrm{HgSe}$ complexes (Kim et al., 1996), which may be depleted in $\delta^{202} \mathrm{Hg}$ values. In the case of the giant petrels, the two individuals presented a low proportion of $\mathrm{MeHg}$ in the liver (3 and 6\%), also suggesting high extent of hepatic demethylation in this species. As previously discussed, the young giant petrel presented a significant increase of $\delta^{202} \mathrm{Hg}$ values from liver to muscle $(0.66$ $\%$ ), being coherent with the trend found in all the individuals of Antarctic prions and white-chinned petrels. However, the high proportion of $\mathrm{Hg}(\mathrm{II})$ observed in the muscle of the old giant petrel, probably due to high accumulation of metabolised $\mathrm{Hg}$ (II) over its lifetime, could contribute to its relatively lower $\delta^{202} \mathrm{Hg}$ value. A recent study on pilot whales (Bolea-Fernandez et al., 2019) observed that HgSe complexes accumulated in the muscles were depleted in $\delta^{202} \mathrm{Hg}$ values relative to the $\mathrm{THg}$ (mostly $\mathrm{MeHg}$ ) in the corresponding muscle tissue. However, the $\mathrm{HgSe}$ complexes formed in livers exhibited higher $\delta^{202} \mathrm{Hg}$ values than the THg of the liver, due to the predominance of demethylated (fractionated) $\mathrm{Hg}(\mathrm{II})$ in this tissue. These observations evidenced that the process of $\mathrm{HgSe}$ 
formation from $\mathrm{MeHg}$ favours the co-precipitation of lighter $\mathrm{Hg}$ isotopes and shows the strong influence of $\mathrm{Hg}$ species distribution on the $\mathrm{THg}$ isotopic signature of each tissue (Bolea-Fernandez et al., 2019). The presence of a high fraction of $\mathrm{Hg}(\mathrm{II})$ in the muscle of the old giant petrel, both in the soluble fraction and in the form of precipitated $\mathrm{HgSe}$, could therefore contribute to the depleted $\delta^{202} \mathrm{Hg}$ signatures in the muscle tissue (BoleaFernandez et al., 2019). The different liver $\mathrm{Hg}($ II) proportions and different offset of $\delta^{202} \mathrm{Hg}$ between liver and muscle of the three seabird species seem to be closely related to their species-specific detoxification strategies. Previous studies suggested that seabirds having both a $\mathrm{Hg}$-rich diet and a complex moulting pattern associate excretion of $\mathrm{MeHg}$ into feathers with a high capacity of hepatic demethylation (Kim et al., 1996). MeHg demethylation in the liver is thus supposed to be a complementary detoxification process to Hg excretion by feathers (Nigro and Leonzio, 1996). This overall process appears to be especially significant in Procellariiforms, such as albatrosses and petrels (Wolfe et al., 1998). The $\mathrm{Hg}(\mathrm{II})$ fraction increases with the THg concentrations in the liver of both the white-chinned and giant petrel individuals. The high proportion of $\mathrm{Hg}$ (II) and the generally depleted $\delta^{202} \mathrm{Hg}$ signatures in their livers suggest that these two seabird species present a high extent of hepatic demethylation, as a response to the elevated levels of $\mathrm{Hg}$ exposure by dietary intake. In contrast, the minor presence of $\mathrm{Hg}(\mathrm{II})$ and the relatively less-depleted $\delta^{202} \mathrm{Hg}$ signatures in the liver of Antarctic prions relative to other tissues (such as muscle) could be indicative of a lower extent of hepatic $\mathrm{Hg}$ demethylation. Because Antarctic prion feeds at a lower trophic level, it is exposed to a lower $\mathrm{MeHg}$ intake and the excretion through the feathers may be sufficiently efficient to detoxify $\mathrm{MeHg}$, thus reducing the need of liver $\mathrm{MeHg}$ demethylation. Although the different extent of hepatic demethylation among seabird species is coherent with their contrasted foraging 
habits, the differences of $\mathrm{Hg}$ MDF between liver and muscle could be also induced by the level of $\mathrm{MeHg}$ exposure due to their diet. Seabirds exposed to elevated $\mathrm{MeHg}$ concentrations could demethylate a relatively low fraction of $\mathrm{MeHg}$ in relation to the whole $\mathrm{MeHg}$ intake, thus inducing higher $\mathrm{Hg}$ MDF between the demethylated $\mathrm{Hg}$ (II) fraction in liver and the residual $\mathrm{MeHg}$ remobilised in muscles. Consequently, a more advanced interpretation of the isotopic trends of $\mathrm{Hg}$ in the hepatic and muscular tissues requires knowing the respective turnover rates of $\mathrm{Hg}$ species in each organ.

\subsubsection{Insights of $\mathrm{MeHg}$ feather excretion}

The decrease of $\mathrm{Hg}$ concentrations in seabird tissues during feather growth had led to the conclusion that $\mathrm{MeHg}$ accumulated in the body is (partly) remobilized into growing feathers for excretion (Furness et al., 1986; Braune, 1987). In this study, an enrichment of $\delta^{202} \mathrm{Hg}$ values from muscles to feathers in the three seabird species suggests the excretion of isotopically heavier $\mathrm{MeHg}$ for detoxification during moult. The difference of $\delta^{202} \mathrm{Hg}$ values between both tissues was particularly significant in giant petrels $(\sim 1.88$ $\%$ ), followed by Antarctic prions $(\sim 0.95 \%)$ and white-chinned petrels $(\sim 0.81 \%$ ). The specific differences of $\delta^{202} \mathrm{Hg}$ values between tissues seem to indicate that the $\delta^{202} \mathrm{Hg}$ values are closely related to the proportion of $\mathrm{Hg}$ (II) (from the demethylation of $\mathrm{MeHg}$ ) present in each organ. For instance, giant petrels exhibited the highest fraction of $\mathrm{MeHg}$ in feathers ( $97 \%$ for the three individuals), whereas the $\mathrm{MeHg}$ percentage in their muscles was much lower, varying from 38 to $58 \%$. The $\mathrm{Hg}$ (II) fraction present in the muscle tissue is characterized by a lower $\delta^{202} \mathrm{Hg}$ compared to the $\mathrm{MeHg}$ fraction. Therefore, the difference on $\mathrm{Hg}$ speciation contributes to the offset of $\delta^{202} \mathrm{Hg}$ values between both tissues. In the case of Antarctic prions and white-chinned petrels, the difference of $\% \mathrm{MeHg}$ between feathers (mean values 94 and 96\%, respectively) and muscles (84 and 
$77 \%$, respectively) was not that pronounced, and therefore lower differences of $\delta^{202} \mathrm{Hg}$ values were found between both tissues. The increases of $\delta^{202} \mathrm{Hg}$ values and $\% \mathrm{MeHg}$ from muscles to feathers of the three seabirds indicate a remobilisation of the $\mathrm{MeHg}$ fraction from muscles towards the feathers and support the previous assumptions of major role of moult in $\mathrm{MeHg}$ excretion. It is well-established that $\mathrm{MeHg}$ presents a high affinity for thiol-containing compounds such as cysteine, a major constituent of keratins which forms the growing feather. MeHg-cysteine complexes are known to be transferred across the blood-brain barrier (Clarkson and Magos, 2006) and across membranes to liver and kidneys (Bridges and Zalups, 2010). Therefore, increasing $\delta^{202} \mathrm{Hg}$ values from internal tissues to feathers could be attributed to an intrinsic process, such as kinetical isotopic fractionation during complexation of $\mathrm{MeHg}$ to cysteine or during inter-tissue transport by bloodstream. Previous works have reported a difference of $\sim 2 \%$ in $\delta^{202} \mathrm{Hg}$ signatures MeHg excreted in human hair relative to their consumed seafood (Laffont et al., 2011; Sherman et al., 2013; Li et al., 2014). This observation also supports the occurrence of similar metabolic pathways in seabirds by excretion through feather growth.

The three seabird species exhibited transitional $\delta^{202} \mathrm{Hg}$ values in muscles relative to liver and feathers. We could suppose that the isotopically heavier fraction of non-demethylated $\mathrm{MeHg}$ in the liver of seabirds is redistributed into the muscle, thus enriching $\delta^{202} \mathrm{Hg}$ values in this storage organ. Then, muscle is an intermediate organ that accumulates the $\mathrm{MeHg}$ non demethylated in the liver before the remobilisation toward feathers for excretion during moult. The enrichment in $\delta^{202} \mathrm{Hg}$ values from internal muscles to feathers could be therefore explained by preferential complexation of isotopically heavier $\mathrm{MeHg}$ with proteins which forms the growing feather. Further, we should consider that the inter-tissue $\mathrm{Hg}$ isotopic variations would be also affected by the $\mathrm{Hg}$ burden and turnover of each 
organ, and therefore the degree of exposure to $\mathrm{Hg}$ of each seabird species. For instance, the high amounts of $\mathrm{MeHg}$ ingested by white-chinned and giant petrels lead to higher $\mathrm{Hg}$ amounts stored in their body compared to low trophic-level seabirds such as Antarctic prions. A high amount of $\mathrm{Hg}$ accumulated in the internal tissues could lead to a so-called "reservoir effect". This means that the influence of recently acquired $\mathrm{Hg}$ into the isotopic composition is reduced due to the high $\mathrm{Hg}$ body burden, thus producing an equilibration of $\Delta^{199} \mathrm{Hg}$ values within the different tissues. Therefore, the specific levels of $\mathrm{Hg}$ body burden of each seabird species could lead to different offset of $\Delta^{199} \mathrm{Hg}$ signatures among their tissues.

Additionally, we measured $\mathrm{Hg}$ isotopes in blood, brain and kidneys of the three giant petrels. Although we cannot made conclusive interpretations due to the low number of individuals available, the results give some insights about the general $\mathrm{Hg}$ metabolic processes in this species at different life-stages (further discussion in SI). For instance, blood samples of giant petrels (high $\% \mathrm{MeHg}$ ) exhibited heavier $\delta^{202} \mathrm{Hg}$ values than internal organs, varying from 1.61 to $2.30 \%$. This trend is consistent with previous observations on long-finned pilot whales that also reported higher $\delta^{202} \mathrm{Hg}$ values in blood compared to internal tissues, such as muscles, liver or kidneys (Bolea-Fernandez et al., 2019). The presence of isotopically heavier MeHg fraction in blood relative to other internal tissues (brain, kidneys and liver) has also been observed in captive minks (Ma et al., 2016). Similarly, $\mathrm{Hg}$ isotopic signatures of mink fur were similar to that of the blood, which was attributed to only one-direction blood to fur transport (Ma et al., 2016). Similar $\delta^{202} \mathrm{Hg}$ (and $\Delta^{199} \mathrm{Hg}$ ) values between blood and feathers in giant petrels support the assumption that bloodstream transports $\mathrm{MeHg}$ throughout the internal tissues and 
represents an intermediate vector between dietary $\mathrm{Hg}$ assimilation and tissue $\mathrm{Hg}$ redistribution (Fournier et al., 2002).

\section{3 $\mathrm{Hg}$ MIF values related to specific ecological characteristics}

Photochemical reactions of $\mathrm{MeHg}$ and $\mathrm{Hg}$ (II) in the water column are the main drivers of $\mathrm{Hg}$ (odd) MIF values (Bergquist and Blum, 2007). Each photochemical process is characterized by a different $\Delta^{199} \mathrm{Hg} / \Delta^{201} \mathrm{Hg}$ ratio that is used to identify mechanisms involving MIF variations. $\Delta^{199} \mathrm{Hg} / \Delta^{201} \mathrm{Hg}$ slopes have been experimentally estimated during MeHg photodemethylation $(1.36 \pm 0.02)$ and $\mathrm{Hg}(\mathrm{II})$ photoreduction $(1.00 \pm 0.02)$ in aquatic compartments (Bergquist and Blum, 2007). The $\Delta^{199} \mathrm{Hg} / \Delta^{201} \mathrm{Hg}$ ratios calculated for the tissues of the three seabird species (Fig S2) are in line with slopes previously reported in marine organisms (Day et al., 2012; Masbou et al., 2015, 2018; Perrot et al., 2016; Renedo et al., 2018a, 2018b). Since Hg MIF is thought to be unaltered by $\mathrm{Hg}$ metabolic processes, no changes in $\Delta^{199} \mathrm{Hg}$ values were expected among seabird tissues. Interestingly, we observed inter-tissue differences of $\Delta^{199} \mathrm{Hg}$ values that could be linked to species-specific ecological characteristics.

$\Delta^{199} \mathrm{Hg}$ values of feathers of Antarctic prions (2.37 $\left.\pm 0.10 \%\right)$ were significantly higher compared to values of muscles and livers $(1.93 \pm 0.14$ and $1.90 \pm 0.05 \%$, respectively $)$ $(\mathrm{H}=17.36, \mathrm{p}<0.0001)$ (Fig. 3). Similar $\Delta^{199} \mathrm{Hg} / \Delta^{201} \mathrm{Hg}$ ratios between the three studied tissues of Antarctic prions (ANOVA, $\mathrm{F}=0.005, \mathrm{p}=0.995, \mathrm{n}=25$ ) indicate that the $\mathrm{MeHg}$ accumulated by diet had undergone the same type of photochemical mechanisms prior to incorporation in the food web (Fig S2). In the case of white-chinned petrels, $\Delta^{199} \mathrm{Hg}$ values were significantly different among the three analysed tissues $(H=20.97$, $\mathrm{p}<0.0001)$, with higher mean $\Delta^{199} \mathrm{Hg}$ values in feathers $(1.49 \pm 0.21 \%$ ), then muscles 
$\left(1.29 \pm 0.07 \%\right.$ ) and livers $(1.17 \pm 0.05 \%)$. Interestingly, the $\Delta^{199} \mathrm{Hg} / \Delta^{201} \mathrm{Hg}$ ratio was significantly higher in feathers $(1.26 \pm 0.08)$ than in internal tissues $(H=13.80, p=0.001)$ (Fig. S2). In contrast to these two seabird species, no significant variations of $\Delta^{199} \mathrm{Hg}$ values were observed among different tissues of southern giant petrels $(\mathrm{H}=5.54$, $\mathrm{p}=0.353)$. Due to the low number of individuals of giant petrel, the $\Delta^{199} \mathrm{Hg} / \Delta^{201} \mathrm{Hg}$ ratio for this species was calculated considering all the tissues and individuals together and exhibited a slope of $1.06 \pm 0.19$ (Fig. S2).

The significant difference of $\Delta^{199} \mathrm{Hg}$ values between feathers and internal tissues in Antarctic prions and white-chinned petrels indicates that the $\mathrm{MeHg}$ excreted into the feathers was more photochemically impacted than the $\mathrm{MeHg}$ accumulated in internal tissues of these two species. We hypothesized that this evidence could be mostly related to specific integration times of $\mathrm{Hg}$ exposure between tissues. Muscles and livers are relatively active tissues whereas feathers integrate $\mathrm{Hg}$ excreted during their period of growth, and once synthetized they are metabolically inert (Bearhop et al., 2000). The existence of different turnover among internal tissues (relatively dynamic active tissues) and feathers (inert storage tissues after synthesis) could then induce a temporal and geographical mismatch of $\mathrm{Hg}$ exposure within seabird samples. Feather moult in Antarctic prions and white-chinned petrels occurs annually during their inter-breeding periods (Cherel et al., 2016). Assuming an efficient remobilisation of MeHg during moult, feathers are supposed to mostly integrate $\mathrm{Hg}$ bioaccumulated between two moults, i.e. during 1 year of exposure. Previous studies found that approximately $70-90 \%$ of the stored $\mathrm{Hg}$ since the last moult is excreted into the new plumage (Honda et al., 1986; Braune, 1987; Agusa et al., 2005). Therefore, the Hg accumulated in internal tissues would be rather a mixture of recently $\mathrm{MeHg}$ uptake and the remaining fraction of $\mathrm{MeHg}$ 
(10-30\%) that was not excreted during the moult and was ingested at previous periods of their life. Tissue-specific accumulation and/or turnover of $\mathrm{Hg}$ corresponding to different temporal windows of $\mathrm{Hg}$ exposure may therefore lead to slight shifts in $\Delta^{199} \mathrm{Hg}$ values between feathers and internal tissues.

Antarctic prions are known to forage on crustaceans at the sea surface, where high extents of photoreduction of $\mathrm{Hg}(\mathrm{II})$ and photodemethylation of $\mathrm{MeHg}$ induce positive odd-MIF in the residual $\mathrm{Hg}(\mathrm{II})$ and $\mathrm{MeHg}$. As evidenced in previous work in the North Pacific Ocean (Blum et al., 2013), the dilution of surface MeHg with non-photochemically impacted $\mathrm{MeHg}$ produced at depth leads to a consistent decrease of $\mathrm{Hg}$ isotopes (both MDF and MIF) in fish according to foraging depths. Therefore, changes of feeding behaviour or distinct foraging zones of seabirds among their annual cycle could induce inter-tissue $\Delta^{199} \mathrm{Hg}$ variability, as previously observed in blood and feathers of adult penguins (Renedo et al., 2018b). Since Antarctic prions have a constant pelagic crustacean-based diet over the year (Cherel et al., 2016), the higher $\Delta^{199} \mathrm{Hg}$ values in their feathers do not seem to be related to changing foraging depths during their annual cycle. However, this seabird is known to migrate to warmer subtropical waters during interbreeding periods (Cherel et al., 2016) and they assimilate MeHg from different marine pools both at the breeding site (subantarctic and Antarctic during their chick-rearing period) and during their winter migration far from their colonies (subtropical). A recent study on resident seabirds showed higher $\left(\sim 0.6 \%\right.$ ) blood $\Delta^{199} \mathrm{Hg}$ values in subtropical populations relative to Antarctic populations as a result of higher extent of $\mathrm{MeHg}$ photodemethylation at subtropical latitudes (Renedo et al., 2018b). This observation supports that the higher $\Delta^{199} \mathrm{Hg}$ values in feathers could be associated to the assimilation of more photochemically impacted $\mathrm{MeHg}$ from subtropical habitats during the inter- 
breeding period. Since the period in subtropical waters represents a significant part of their whole year cycle of Antarctic prions ( 230 days, Cherel et al., 2016), the impact of the $\mathrm{Hg}$ uptake with subtropical $\mathrm{Hg}$ isotopic signature should be significant.

In the same way, white-chinned petrels from Kerguelen Islands forage from subantarctic to Antarctic waters and winter in the Benguela Current (Jackson, 1988; Delord et al., 2010; Péron et al., 2010). Their migratory movements and changing latitudinal zones could then contribute to the uptake of $\mathrm{MeHg}$ from different biogeochemical reservoirs that have different "endmember" $\Delta^{199} \mathrm{Hg}$ and $\Delta^{201} \mathrm{Hg}$ values. However, the $\Delta^{199} \mathrm{Hg}$ difference between feathers and muscles of white-chinned petrels was much lower $(\sim 0.2$ \%) than the observed in Antarctic prions ( $\sim 0.6 \%$ ). We could associate this difference to a less influence of the MeHg uptake in subtropical food webs in white-chinned petrels due to their shorter inter-breeding period in subtropical waters ( 180 days) (Péron et al., 2010). Further, the high Hg exposure levels of white-chinned petrels could lead to the previously commented "reservoir effect". The high amount of MeHg uptake during the breeding period (with lower MIF values) accumulated in their livers and muscles is mixed with the $\mathrm{MeHg}$ fraction assimilated during inter-breeding periods (with higher MIF values), which is mainly excreted by feather moult. Therefore, the specific levels of $\mathrm{Hg}$ body burden of each seabird species could lead to different offset of $\Delta^{199} \mathrm{Hg}$ signatures among their tissues. The significant difference of $\Delta^{199} \mathrm{Hg}$ values between muscle and liver tissues of white-chinned petrels $(\sim 0.15 \%)$ contrasts with the pattern observed in Antarctic prions. Seasonal shifts of their foraging habits over their annual cycle could lead to the consumption of different $\mathrm{Hg}$ (II) fractions, which could potentially induce the assimilation of $\mathrm{Hg}$ from different reservoirs (different $\Delta^{199} \mathrm{Hg}$ values) and $\mathrm{Hg}$ speciesspecific accumulation between muscles and livers (Feng et al., 2015). However, the diet 
of white-chinned petrels is mainly composed on pelagic organisms (crustaceans, fish and cephalopods) over their whole annual cycle, thus the contribution of isotopically different prey would be minor. Consequently, the different $\Delta^{199} \mathrm{Hg}$ values between muscles and liver of white-chinned petrels mostly reflect a different biological turnover or different $\mathrm{Hg}$ residence time in tissues of this species. Muscles are assumed to be long-term storage tissues, whereas liver represents a dynamic detoxification organ. More efficient hepatic $\mathrm{Hg}$ demethylation or excretion in white-chinned petrels could induce a lower remobilisation of residual non-demethylated $\mathrm{MeHg}$ from liver to muscles, potentially increasing the temporal mismatch (and the $\Delta^{199} \mathrm{Hg}$ values) of the accumulated $\mathrm{Hg}$ between both tissues. Again, an influence of the high $\mathrm{Hg}$ burden in this high-trophic level species (reservoir effect) could influence the inter-tissue $\mathrm{Hg}$ isotopic variations.

In the case of southern giant petrels, all the analysed tissues exhibited similar $\Delta^{199} \mathrm{Hg}$ values. We hypothesized that the elevated $\mathrm{Hg}$ concentrations in the body of this species could lead to less influence of the recently acquired $\mathrm{Hg}$ into the isotopic composition, thus producing an equilibration of $\Delta^{199} \mathrm{Hg}$ values within the different tissues (reservoir effect). We could assume that southern giant petrels moult almost continuously leading to the direct excretion of the dietary $\mathrm{Hg}$, as observed for albatrosses (Cherel et al., 2018). Therefore, a different moulting pattern may consequently minimize the variations of $\Delta^{199} \mathrm{Hg}$ values among internal tissues and feathers.

\section{Conclusion}

Measurements of $\mathrm{Hg}$ stable isotopes and $\mathrm{Hg}$ speciation in seabird tissues allowed a deep exploration of key metabolic strategies and capacities of species according to their ecological characteristics. Variations of $\delta^{202} \mathrm{Hg}$ values among internal tissues and feathers 
evidenced $\mathrm{MeHg}$ hepatic demethylation and $\mathrm{MeHg}$ excretion by moulting feathers in seabirds as a metabolic response to $\mathrm{MeHg}$ toxicity. These two processes seem to occur in different extent between seabird species and to be dependent on their specific physiological capacities and levels of exposure to dietary MeHg. Different $\mathrm{Hg}$ integration times between feathers and internal tissues lead to differences in $\Delta^{199} \mathrm{Hg}$ values and then allow investigating different temporal and geographical windows during the seabird annual cycle. Internal tissues, with a relative active $\mathrm{Hg}$ turnover, reflect a mixture of recently uptake of $\mathrm{MeHg}$ and $\mathrm{Hg}$ accumulated over time and can provide valuable information about $\mathrm{Hg}$ accumulation and metabolic response. The use of other tissues with more precise $\mathrm{Hg}$ temporal integration windows, such as blood (weeks to few months) or feathers ( one year), makes them more sensitive to trace $\mathrm{Hg}$ spatio-temporal exposure.

\section{Acknowledgments}

The authors wish to thank the fieldworkers who collected the samples, including the TAAF fishery observer N. Gasco who sampled white-chinned petrels. Field procedures were authorized by the Comité d'Ethique of the Institut Polaire Français Paul Emile Victor (IPEV) and by the Comité de l'Environnement Polaire. This study received financial and logistical support from the IPEV (program no. 109, H. Weimerskirch) and the Terres Australes et Antarctiques Françaises (TAAF). It was supported financially by the Région Poitou-Charentes (now the Région Nouvelle Aquitaine) through a Ph.D. scholarship to MR, and by the French national program EC2CO Biohefect/Ecodyn//Dril/MicrobiEen (TIMOTAAF project, P.I. D. Amouroux). The IUF (Institut Universitaire de France) is also acknowledged for its support to PB as a senior member. 

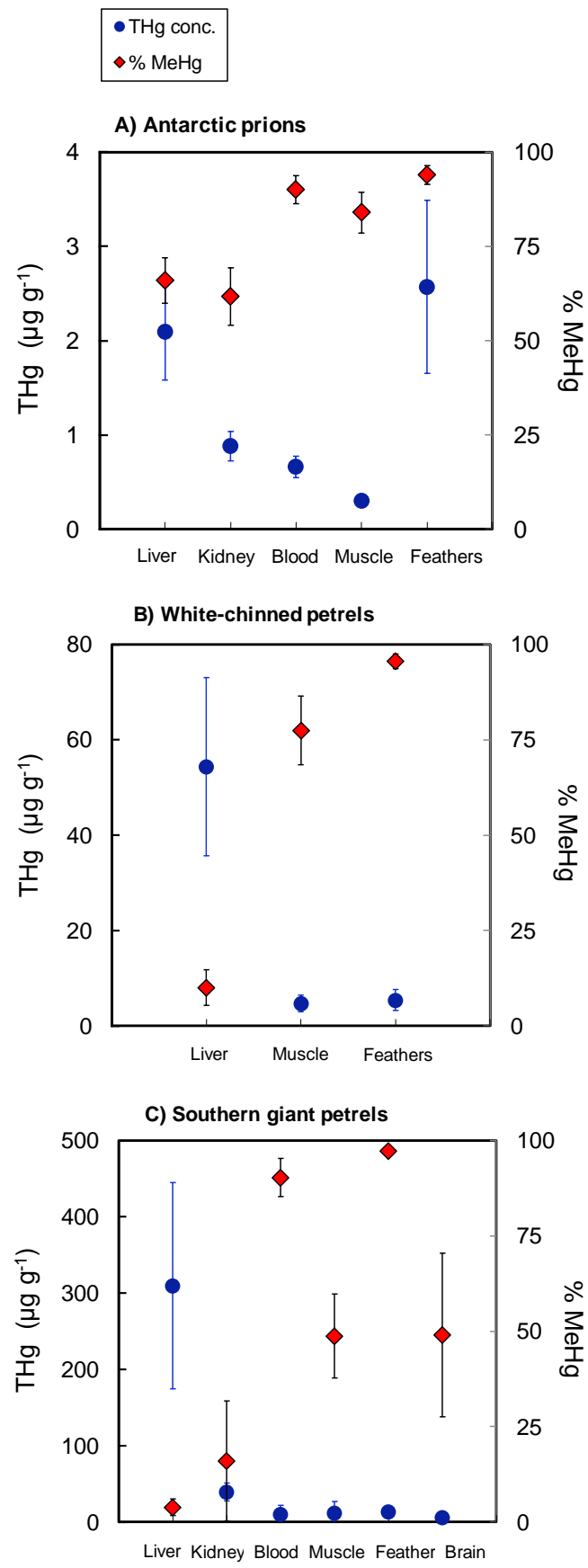

Figure 1. Mean total $\mathrm{Hg}$ concentrations ( $\mu \mathrm{g} \mathrm{g}^{-1}$, blue circles) and $\mathrm{Hg}$ speciation (as \% $\mathrm{MeHg}$, red diamonds) in tissues of A) Antarctic prions ( $n=10), B)$ white-chinned petrels $(n=10), C)$ southern giant petrels $(n=3$, except livers $n=2)$. 


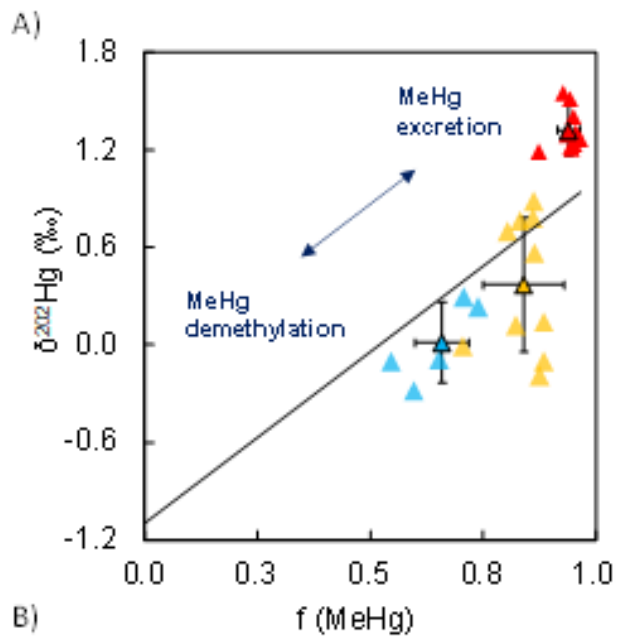

\section{Antarctic prions}

$\Delta$ Liver

$\Delta$ Muscle

$\Delta$ Feathers

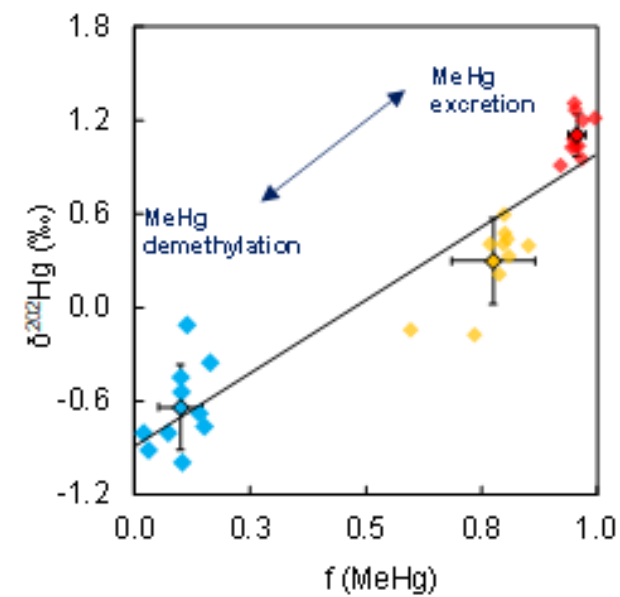

White-chinned petrels

$\diamond$ Liver

$\diamond$ Muscle

- Feathers

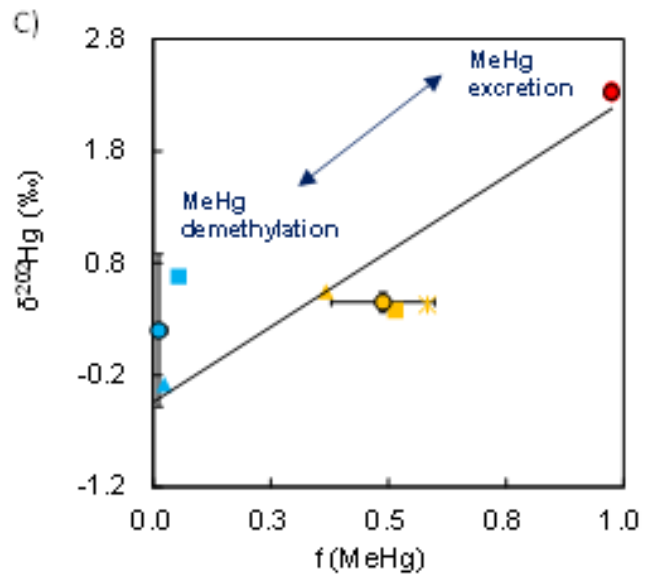

Southern giant petrels

\begin{tabular}{l|l|l|}
\hline - Liver & $\begin{array}{l}\Delta \text { Juvenile } \\
\text { - Mduscle } \\
\text { - Feathers } \\
\text { - Old }\end{array}$ \\
\hline
\end{tabular}

Figure 2. Hg MDF (as $\delta^{202} \mathrm{Hg}$ ) relative to the percentage of MeHg. Regression lines Antarctic prions $(n=10)$ : $y=2.11 x-1.10$, Spearman correlation coefficients $R^{2}=0.76, p<0.0001$; whitechinned petrels $(n=10): y=1.87 x-0.89$, Spearman correlation coefficients were $R^{2}=0.93, p<$ 0.0001 ; giant petrels $(n=3): y=2.2717 x-0.1611$, Spearman correlation coefficients $R^{2}=0.75, p$ $<0.0001$. Highlighted symbols with error bars represent mean \pm SD values for each tissue. Whole data and associated statistics are included in SI (Table S3, S4 and S5). 


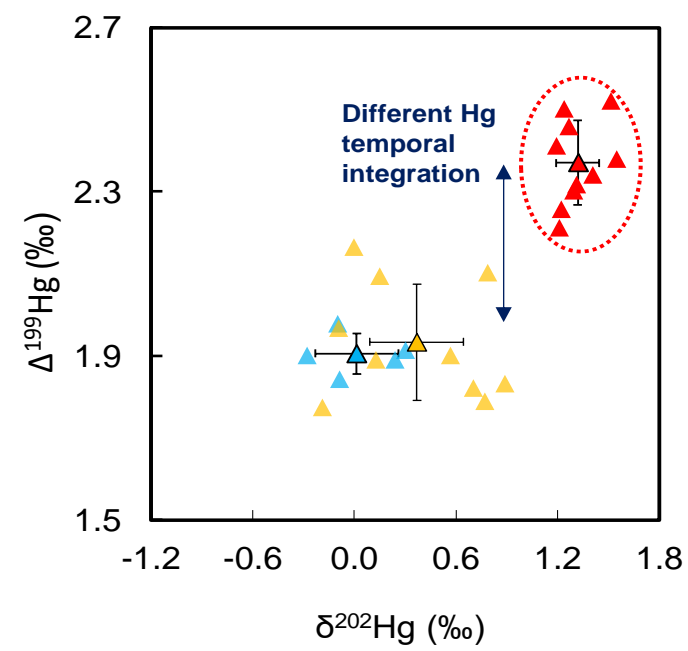

\section{Antarctic prions}

$\Delta$ Liver

$\triangle$ Muscle

$\Delta$ Feathers

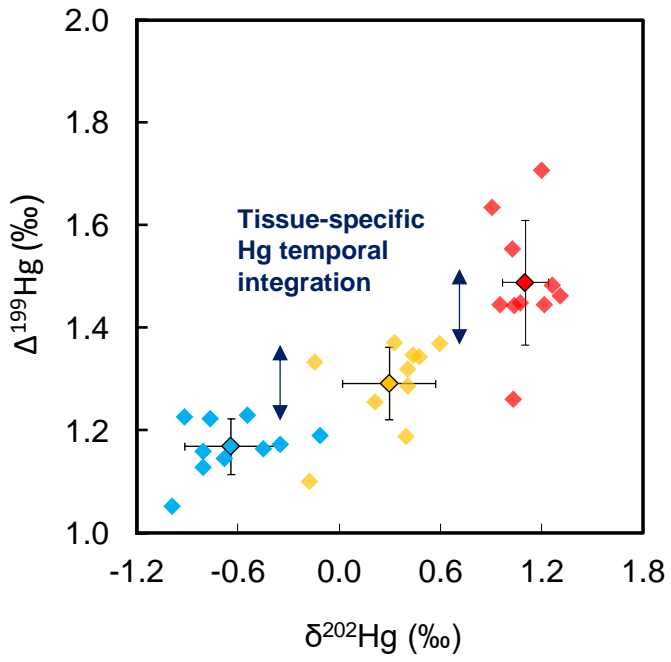

White-chinned petrels

$\diamond$ Liver

$\diamond$ Muscle

$\diamond$ Feathers

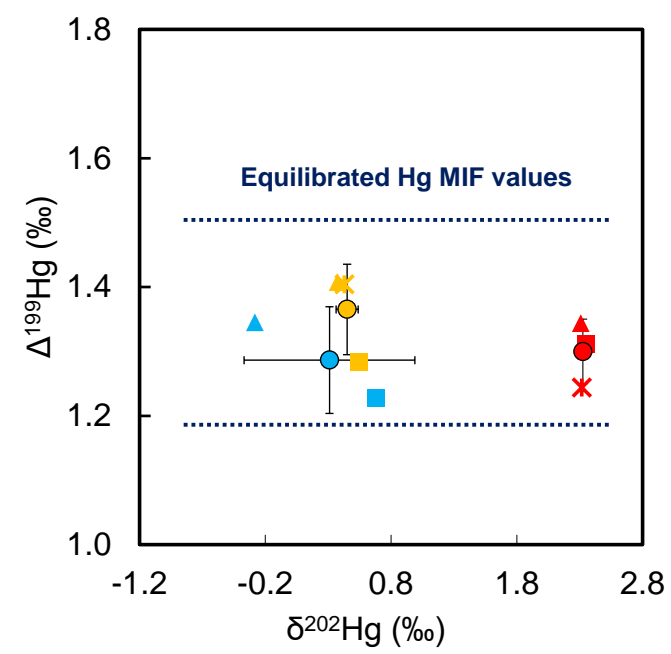

Southern giant petrels

\begin{tabular}{|l|l|}
\hline - Liver & $\begin{array}{l}\Delta \text { Juvenile } \\
\text { Muscle } \\
\text { - Feathers }\end{array}$ \\
\hline
\end{tabular}

Figure 4. $\mathrm{Hg}$ MDF $v s \mathrm{Hg}$ MIF (expressed as $\delta^{202} \mathrm{Hg}$ and $\Delta^{199} \mathrm{Hg}$, respectively) of livers, muscles and feathers of Antarctic prions ( $\mathrm{n}=10)$, white-chinned petrels $(\mathrm{n}=10)$ and southern giant petrels $(n=3)$. Highlighted symbols with error bars represent mean \pm SD values for each tissue. Whole data and associated statistics are included in SI (Table S3, S4 and S5). 


\section{References}

Agusa, T., Matsumoto, T., Ikemoto, T., Anan, Y., Kubota, R., Yasunaga, G., Kunito, T., Tanabe, S., Ogi, H., Shibata, Y., 2005. Body distribution of trace elements in black-tailed gulls from Rishiri Island, Japan: Age-dependent accumulation and transfer to feathers and eggs. Environ. Toxicol. Chem. 24, 2107-2120. https://doi.org/10.1897/04-617R.1

Andrews, G.K., Fernando, L.P., Moore, K.L., Dalton, T.I.M.P., Sobieskif, R.J., 1996. Avian Metallothioneins : Structure, regulation and evolution. Am. Inst. Nutr. 3, 1308-1316.

Arai, T., Ikemoto, T., Hokura, A., Terada, Y., Kunito, T., Tanabe, S., Nakai, I., 2004. Chemical forms of mercury and cadmium accumulated in marine mammals and seabirds as determined by XAFS analysis. Environ. Sci. Technol. 38, 6468-6474. https://doi.org/10.1021/es040367u

Bearhop, S., Ruxton, G.D., Furness, R.W., 2000a. Dynamics of mercury in blood and feathers of great skuas. Environ. Toxicol. Chem. 19, 1638-1643. https://doi.org/10.1897/15515028(2000)019<1638:Domiba>2.3.Co;2

Bearhop, S., Ruxton, G.D., Furness, R.W., 2000b. Dynamics of mercury in blood and feathers of greet skuas. Environ. Toxicol. Chem. 19, 1638-1643. https://doi.org/Doi 10.1897/15515028(2000)019<1638:Domiba >2.3.Co;2

Bergquist, B.A., Blum, J.D., 2007. Mass-dependent and -independent fractionation of $\mathrm{Hg}$ isotopes by photoreduction in aquatic systems. Science 318, 417-20. https://doi.org/10.1126/science.1148050

Blum, J.D., Bergquist, B. a., 2007. Reporting of variations in the natural isotopic composition of mercury. Anal. Bioanal. Chem. 388, 353-359. https://doi.org/10.1007/s00216-007-1236-9

Blum, J.D., Popp, B.N., Drazen, J.C., Anela Choy, C., Johnson, M.W., 2013. Methylmercury production below the mixed layer in the North Pacific Ocean. Nat. Geosci. 6, 879-884. https://doi.org/10.1038/ngeo1918

Bolea-Fernandez, E., Rua-Ibarz, A., Krupp, E.M., Feldmann, J., Vanhaecke, F., 2019. Highprecision isotopic analysis sheds new light on mercury metabolism in long-finned pilot whales (Globicephala melas). Sci. Rep. 9, 1-10. https://doi.org/10.1038/s41598-01943825-z

Braune, B.M., 1987. Comparison of total mercury levels in relation to diet and molt for nine species of marine birds. Arch. Environ. Contam. Toxicol 16, 217-224.

Braune, B.M., Scheuhammer, A.M., 2008. Trace element and metallothionein concentrations in seabirds from the Canadian arctic. Environ. Toxicol. Chem. 27, 645-651. https://doi.org/10.1897/07-269.1

Bridges, C.C., Zalups, R.K., 2010. Transport of inorganic mercury and methylmercury in target tissues and organs. J. Toxicol. Environ. Health. B. Crit. Rev. 13, 385-410. https://doi.org/10.1080/10937401003673750

Carravieri, A., Bustamante, P., Churlaud, C., Cherel, Y., 2013. Penguins as bioindicators of mercury contamination in the Southern Ocean: birds from the Kerguelen Islands as a case 
study. Sci. Total Environ. 454-455, 141-8. https://doi.org/10.1016/j.scitotenv.2013.02.060

Carravieri, A., Bustamante, P., Tartu, S., Meillère, A., Labadie, P., Budzinski, H., Peluhet, L., Barbraud, C., Weimerskirch, H., Chastel, O., Cherel, Y., 2014. Wandering albatrosses document latitudinal variations in the transfer of persistent organic pollutants and mercury to southern ocean predators. Environ. Sci. Technol. 48, 14746-14755. https://doi.org/10.1021/es504601m

Cherel, Y., Barbraud, C., Lahournat, M., Jaeger, A., Jaquemet, S., Wanless, R.M., Phillips, R.A., Thompson, D.R., Bustamante, P., 2018. Accumulate or eliminate? Seasonal mercury dynamics in albatrosses, the most contaminated family of birds. Environ. Pollut. 241, 124135. https://doi.org/10.1016/j.envpol.2018.05.048

Cherel, Y., Bocher, P., Broyer, C. De, Hobson, K.A., 2002. Food and feeding ecology of the sympatric thin- billed Pachyptila belcheri and Antarctic P . desolata prions at Iles Kerguelen , Southern Indian Ocean 228, 263-281.

Cherel, Y., Quillfeldt, P., Delord, K., Weimerskirch, H., 2016. Combination of At-Sea Activity , Geolocation and Feather Stable Isotopes Documents Where and When Seabirds Molt. Front. Ecol. Evol. 4. https://doi.org/10.3389/fevo.2016.00003

Cipro, C.V.Z., Cherel, Y., Caurant, F., Miramand, P., Méndez-Fernandez, P., Bustamante, P., 2014. Trace elements in tissues of white-chinned petrels (Procellaria aequinoctialis) from Kerguelen waters, Southern Indian Ocean. Polar Biol. 37, 763-771. https://doi.org/10.1007/s00300-014-1476-z

Clarkson, T.W., Magos, L., 2006. The toxicology of mercury and its chemical compounds. Crit. Rev. Toxicol. 36, 609-662. https://doi.org/10.1080/10408440600845619

Clémens, S., Monperrus, M., Donard, O.F.X., Amouroux, D., Guérin, T., 2011. Mercury speciation analysis in seafood by species-specific isotope dilution: method validation and occurrence data. Anal Bioanal Chem 401, 2699-2711. https://doi.org/10.1007/s00216-011$5040-1$

Cuvin-Aralar, M.L.A., Furness, R.W., 1991. Mercury and selenium interaction: A review. Ecotoxicol. Environ. Saf. 21, 348-364. https://doi.org/10.1016/0147-6513(91)90074-Y

Das, K., Jacob, V., Bouquegneau, J.M., 2001. White-sided dolphin metallothioneins: Purification, characterisation and potential role. Comp. Biochem. Physiol. - C Toxicol. Pharmacol. 131, 245-251. https://doi.org/10.1016/S1532-0456(02)00011-X

Day, R.D., Roseneau, D.G., Berail, S., Hobson, K. a., Donard, O.F.X., Vander Pol, S.S., Pugh, R.S., Moors, A.J., Long, S.E., Becker, P.R., 2012. Mercury stable isotopes in seabird eggs reflect a gradient from terrestrial geogenic to oceanic mercury reservoirs. Environ. Sci. Technol. 46, 5327-5335. https://doi.org/10.1021/es2047156

Delord, K., Cotté, C., Péron, C., Marteau, C., Pruvost, P., Gasco, N., Duhamel, G., Cherel, Y., Weimerskirch, H., 2010. At-sea distribution and diet of an endangered top predator: Relationship between white-chinned petrels and commercial longline fisheries. Endanger. Species Res. 13, 1-16. https://doi.org/10.3354/esr00309

Dietz, R., Nielsen, C.O., Hansen, M.M., Hansen, C.T., 1990. Organic mercury in Greenland birds and mammals $95,41-51$. 
Elliott, J.E., Scheuhammer, A.M., 1997. Heavy metal and metallothionein concentrations in seabirds from the Pacific coast of Canada. Mar. Pollut. Bull. 34, 794-801. https://doi.org/10.1016/S0025-326X(97)00034-9

Elliott, J.E., Scheuhammer, A.M., Leighton, F.A., Pearce, P.A., 1992. Heavy metal and metallothionein concentrations in Atlantic Canadian seabirds. Arch. Environ. Contam. Toxicol. 22, 63-73. https://doi.org/10.1007/BF00213303

Evers, D.C., Savoy, L.J., Desorbo, C.R., Yates, D.E., Hanson, W., Taylor, K.M., Siegel, L.S., Cooley, J.H., Bank, M.S., Major, A., Munney, K., Mower, B.F., Vogel, H.S., Schoch, N., Pokras, M., Goodale, M.W., Fair, J., 2008. Adverse effects from environmental mercury loads on breeding common loons. Ecotoxicology 17, 69-81. https://doi.org/10.1007/s10646-007-0168-7

Feng, C., Pedrero, Z., Gentès, S., Barre, J., Renedo, M., Tessier, E., Berail, S., Maury-Brachet, R., Mesmer-Dudons, N., Baudrimont, M., Legeay, A., Maurice, L., Gonzalez, P., Amouroux, D., 2015. Specific pathways of dietary methylmercury and inorganic mercury determined by mercury speciation and isotopic composition in zebrafish (Danio rerio). Environ. Sci. Technol. 49, 12984-12993. https://doi.org/10.1021/acs.est.5b03587

Fournier, F., Karasov, W.H., Kenow, K.P., Meyer, M.W., 2002. The oral bioavailability and toxicokinetics of methylmercury in common loon (Gavia immer) chicks. Comp. Biochem. Physiol. 133, 1-12.

Fromant, A., Carravieri, A., Bustamante, P., Labadie, P., Budzinski, H., Peluhet, L., Churlaud, C., Chastel, O., Cherel, Y., 2016. Wide range of metallic and organic contaminants in various tissues of the Antarctic prion, a planktonophagous seabird from the Southern Ocean. Sci. Total Environ. 544, 754-764. https://doi.org/10.1016/j.scitotenv.2015.11.114

Furness, R.W., Muirhead, S.J., Woodburn, M., 1986. Using bird feathers to measure mercury in the environment: Relationships between mercury content and moult. Mar. Pollut. Bull. 17, 27-30. https://doi.org/10.1016/0025-326X(86)90801-5

Gajdosechova, Z., Lawan, M.M., Urgast, D.S., Raab, A., Scheckel, K.G., Lombi, E., Kopittke, P.M., Loeschner, K., Larsen, E.H., Woods, G., Brownlow, A., Read, F.L., Feldmann, J., Krupp, E.M., 2016. In vivo formation of natural HgSe nanoparticles in the liver and brain of pilot whales. Sci. Rep. 6, 1-11. https://doi.org/10.1038/srep34361

González-Solís, J., 2002. Activity patterns of giant petrels , Macronectes spp ., using different foraging strategies https://doi.org/10.1007/s002270100684

Goutte, A., Barbraud, C., Meillere, A., Carravieri, A., Bustamante, P., Labadie, P., Budzinski, H., Delord, K., Cherel, Y., Weimerskirch, H., Chastel, O., 2014a. Demographic consequences of heavy metals and persistent organic pollutants in a vulnerable long-lived bird, the wandering albatross. Proc. R. Soc. B Biol. Sci. 281. https://doi.org/10.1098/rspb.2013.3313

Goutte, A., Bustamante, P., Barbraud, C., Delord, K., Weimerskirch, H., Chastel, O., 2014b. Demographic responses to mercury exposure in two closely related antarctic top predators. Ecology 95, 1075-1086. https://doi.org/10.1890/13-1229.1

Honda, K., Nasu, T., Tatsukawa, R., 1986. Seasonal changes in mercury accumulation in the black-eared kite, Milvus migrans lineatus. Environ. Pollut. Ser. A, Ecol. Biol. 42, 325-334. https://doi.org/10.1016/0143-1471(86)90016-4 
Ikemoto, T., Kunito, T., Tanaka, H., Baba, N., Miyazaki, N., Tanabe, S., 2004. Environmental Contamination and Detoxification Mechanism of Heavy Metals in Marine Mammals and Seabirds : Interaction of Selenium with Mercury, Silver, Copper, Zinc, and Cadmium in Liver. Arch. Environ. Contam. Toxicol 413, 402-413. https://doi.org/10.1007/s00244-0043188-9

Jackson, S., 1988. Diets of the white-chinned petrel and sooty shearwater in the Southern Benguela Region, South Africa. Condor 90, 20-28.

Kehrig, H.A., Hauser-Davis, R.A., Seixas, T.G., Fillmann, G., 2015. Trace-elements, methylmercury and metallothionein levels in Magellanic penguin (Spheniscus magellanicus) found stranded on the Southern Brazilian coast. Mar. Pollut. Bull. 96, 450455. https://doi.org/10.1016/j.marpolbul.2015.05.006

Kim, E. Y., Murakami, T., Saeki, K., Tatsukawa, R., 1996. Mercury levels and its chemical form in tissues and organs of seabirds. Arch. Environ. Contam. Toxicol. 30, 259-266. https://doi.org/10.1007/BF00215806

Kim, E.Y., Saeki, K., Tanabe, S., Tanaka, H., Tatsukawa, R., 1996. Specific accumulation of mercury and selenium in seabirds. Environ. Pollut. 94, 261-265. https://doi.org/10.1016/S0269-7491(96)00110-8

Kim, Goto, R., Tanabe, S., Tanaka, H., Tatsukawa, R., 1998. Distribution of 14 elements in tissues and organs of oceanic seabirds. Arch. Environ. Contam. Toxicol. 35, 638-645. https://doi.org/10.1007/s002449900426

Koeman, J.., Peeters, W.H.., Koudstaal-Hol, C.H.., Tjioe, P.S., De Goeij, J.J.., 1973. MercurySelenium Correlations in Marine Mammals. Nature 245, 385-386.

Kojadinovic, J., Bustamante, P., Churlaud, C., Cosson, R.P., Le Corre, M., 2007. Mercury in seabird feathers: insight on dietary habits and evidence for exposure levels in the western Indian Ocean. Sci. Total Environ. 384, 194-204. https://doi.org/10.1016/j.scitotenv.2007.05.018

Kritee, K., Barkay, T., Blum, J.D., 2009. Mass dependent stable isotope fractionation of mercury during mer mediated microbial degradation of monomethylmercury. Geochim. Cosmochim. Acta 73, 1285-1296. https://doi.org/10.1016/j.gca.2008.11.038

Kritee, K., Blum, J.D., Johnson, M.W., Bergquist, B.A., Barkay, T., 2007. Mercury stable isotope fractionation during reduction of $\mathrm{Hg}(\mathrm{II})$ to $\mathrm{Hg}(0)$ by mercury resistant microorganisms. Environ. Sci. Technol. 41, 1889-1895. https://doi.org/10.1021/es062019t

Kwon, S.Y., Blum, J.D., Chirby, M. a, Chesney, E.J., 2013a. Application of mercury isotopes for tracing trophic transfer and internal distribution of mercury in marine fish feeding experiments. Environ. Toxicol. Chem. 32, 2322-30. https://doi.org/10.1002/etc.2313

Kwon, S.Y., Blum, J.D., Chirby, M. a, Chesney, E.J., 2013b. Application of mercury isotopes for tracing trophic transfer and internal distribution of mercury in marine fish feeding experiments. Environ. Toxicol. Chem. 32, 2322-30. https://doi.org/10.1002/etc.2313

Laffont, L., Sonke, J.E., Maurice, L., Monrroy, S.L., Chincheros, J., Amouroux, D., Behra, P., 2011. Hg speciation and stable isotope signatures in human hair as a tracer for dietary and occupational exposure to mercury. Environ. Sci. Technol. 45, 9910-9916. 
https://doi.org/10.1021/es202353m

Li, M., Juang, C.A., Ewald, J.D., Yin, R., Mikkelsen, B., Krabbenhoft, D.P., Balcom, P.H., Dassuncao, C., Sunderland, E.M., 2020. Selenium and stable mercury isotopes provide new insights into mercury toxicokinetics in pilot whales. Sci. Total Environ. 710, 136325. https://doi.org/10.1016/j.scitotenv.2019.136325

Li, M., Schartup, A.T., Valberg, A.P., Ewald, J.D., David, P., Yin, R., Balcom, P.H., Sunderland, E.M., 2016. Environmental origins of methylmercury accumulated in subarctic estuarine fish indicated by mercury stable isotopes. Env. Sci Technol 50, 11559-15568. https://doi.org/10.1021/acs.est.6b03206

Li, M., Sherman, L.S., Blum, J.D., Grandjean, P., Mikkelsen, B., Weihe, P., Sunderland, E.M., Shine, J.P., 2014. Assessing sources of human methylmercury exposure using stable mercury isotopes. Environ. Sci. Technol. 48, 8800-8806. https://doi.org/10.1021/es500340r

Ma, L., Evans, R.D., Wang, W., Georg, R.B., 2016. Fractionation of mercury isotopes resulting from tissue partitioning in mink ( Neovison vison ). Env. Sci Technol.

Martoja, R., 1980. Identification of tiemannite as a probable product of demethylation of mercury by selenium in cetaceans. A complement to the scheme of the biological cycle of mercury. Vie Milieu 30, 7-10.

Masbou, J., Sonke, J.E., Amouroux, D., Guillou, G., Becker, P.R., Point, D., 2018. Hg-Stable Isotope Variations in Marine Top Predators of the Western Arctic Ocean. ACS Earth Sp. Chem. 2, 479-490. https://doi.org/10.1021/acsearthspacechem.8b00017

Monteiro, L.R., Costa, V., Furness, R.W., Santos, R.S., 1996. Mercury concentrations in prey fish indicate enhanced bioaccumulation in mesopelagic environments. Mar. Ecol. Prog. Ser. 141, 21-25. https://doi.org/10.3354/meps141021

Monteiro, L.R., Furness, R.W., 2001. Kinetics, dose-response, and excretion of methylmercury in free-living adult Cory's shearwaters. Environ. Sci. Technol. 35, 739-746. https://doi.org/10.1021/es000114a

Nigro, M., Leonzio, C., 1996. Intracellular storage of mercury and selenium in different marine vertebrates. Mar. Ecol. Prog. Ser. 135, 137-143.

Norheim, G., Frøslle, A., 1978. The Degree of Methylation and Organ Distribution of Mercury in Some Birds of Prey in Norway. Acta Pharmacol. Toxicol. (Copenh). 43, 196-204. https://doi.org/10.1111/j.1600-0773.1978.tb02255.x

Palmisano, F., Cardellicchio, N., Zambonin, P.G., 1995. Speciation of mercury in dolphin liver: A two-stage mechanism for the demethylation accumulation process and role of selenium. Mar. Environ. Res. 40, 109-121. https://doi.org/10.1016/0141-1136(94)00142-C

Pedrero, Zoyne, Bridou, R., Mounicou, S., Guyoneaud, R., Monperrus, M., Amouroux, D., 2012. Transformation, localization, and biomolecular binding of $\mathrm{Hg}$ species at subcellular level in methylating and nonmethylating sulfate-reducing bacteria. Environ. Sci. Technol. 46, 11744-51. https://doi.org/10.1021/es302412q

Pedrero, Z, Ouerdane, L., Mounicou, S., Lobinski, R., Monperrus, M., Amouroux, D., 2012. Identification of mercury and other metals complexes with metallothioneins in dolphin liver 
by hydrophilic interaction liquid chromatography with the parallel detection by ICP MS and electrospray hybrid linear/orbital trap MS/MS. Metallomics 4, 473-9. https://doi.org/10.1039/c2mt00006g

Péron, C., Delord, K., Phillips, R.A., Charbonnier, Y., Marteau, C., Louzao, M., Weimerskirch, H., 2010. Seasonal variation in oceanographic habitat and behaviour of white-chinned petrels Procellaria aequinoctialis from Kerguelen Island 416, 267-284. https://doi.org/10.3354/meps08785

Perrot, V., Masbou, J., Pastukhov, M. V., Epov, V.N., Point, D., Bérail, S., Becker, P.R., Sonke, J.E., Amouroux, D., 2016. Natural Hg isotopic composition of different $\mathrm{Hg}$ compounds in mammal tissues as a proxy for in vivo breakdown of toxic methylmercury. Metallomics 8, 170-178. https://doi.org/10.1039/C5MT00286A

Perrot, V., Pastukhov, M. V, Epov, V.N., Husted, S., Donard, O.F.X., Amouroux, D., 2012. Higher mass-independent isotope fractionation of methylmercury in the pelagic food web of Lake Baikal (Russia). Environ. Sci. Technol. 46, 5902-11. https://doi.org/10.1021/es204572g

Point, D., Sonke, J.E., Day, R.D., Roseneau, D.G., Hobson, K.A., Pol, S.S. Vander, Moors, A.J., Pugh, R.S., Donard, O.F.X., Becker, P.R., 2011. Methylmercury photodegradation influenced by sea-ice cover in Arctic marine ecosystems. Nat. Geosci. 4, 1-7. https://doi.org/10.1038/ngeo1049

R Core Team, 2016: A language and Environment for Statistical Computing. R Foundation for Statistical Computing, Vienna, Austria, n.d.

Renedo, M., Amouroux, D., Duval, B., Carravieri, A., Tessier, E., Barre, J., Bérail, S., Pedrero, Z., Cherel, Y., Bustamante, P., 2018a. Seabird Tissues As Efficient Biomonitoring Tools for $\mathrm{Hg}$ Isotopic Investigations: Implications of Using Blood and Feathers from Chicks and Adults. Environ. Sci. Technol. 52, 4227-4234. https://doi.org/10.1021/acs.est.8b00422

Renedo, M., Amouroux, D., Pedrero, Z., Bustamante, P., Cherel, Y., 2018b. Identification of sources and bioaccumulation pathways of $\mathrm{MeHg}$ in subantarctic penguins : a stable isotopic investigation. Sci. Rep. 1-10. https://doi.org/10.1038/s41598-018-27079-9

Renedo, M., Bustamante, P., Tessier, E., Pedrero, Z., Cherel, Y., Amouroux, D., 2017. Assessment of mercury speciation in feathers using species-specific isotope dilution analysis. Talanta 174, 100-110. https://doi.org/10.1016/j.talanta.2017.05.081

Rodriguez Gonzalez, P., Epov, V.N., Bridou, R., Tessier, E., Guyoneaud, R., Monperrus, M., Amouroux, D., 2009. Species-specific stable isotope fractionation of mercury during $\mathrm{Hg}$ (II) methylation by an anaerobic bacteria (Desulfobulbus propionicus) under dark conditions. Environ. Sci. Technol. 43, 9183-9188.

Rollinson, D.P., Dilley, B.J., Ryan, P.G., 2014. Diving behaviour of white-chinned petrels and its relevance for mitigating longline bycatch. Polar Biol. 37, 1301-1308. https://doi.org/10.1007/s00300-014-1521-y

Rua-Ibarz, A., Bolea-Fernandez, E., Maage, A., Frantzen, S., Sanden, M., Vanhaecke, F., 2019. Tracing Mercury Pollution along the Norwegian Coast via Elemental, Speciation, and Isotopic Analysis of Liver and Muscle Tissue of Deep-Water Marine Fish (Brosme brosme). Environ. Sci. Technol. 53, 1776-1785. https://doi.org/10.1021/acs.est.8b04706 
Scheuhammer, A.M., Wong, A.H.K., Bond, D., 1998. Mercury and selenium accumulation in common loons (Gavia immer) and common mergansers (Mergus merganser) from Eastern Canada. Environ. Toxicol. Chem. 17, 197-201. https://doi.org/10.1897/15515028(1998)017<0197:MASAIC >2.3.CO;2

Senn, D.B., Chesney, E.J., Blum, J.D., Bank, M.S., Maage, A., Shine, J.P., 2010. Study of Methylmercury Sources and Trophic Transfer in the Northern Gulf of Mexico. Environ. Sci. Technol. 44, 1630-1637.

Sherman, L.S., Blum, J.D., Franzblau, A., Basu, N., 2013. New insight into biomarkers of human mercury exposure using naturally occurring mercury stable isotopes. Env. Sci Technol 47, 3403-3409. https://doi.org/10.1021/es305250z

Spalding, M.G., Frederick, P.C., McGill, H.C., Bouton, S.N., McDowell, L.R., 2000. Methylmercury accumulation in tissues and its effects on growth and appetite in captive great egrets. J. Wildl. Dis. 36, 411-422. https://doi.org/10.7589/0090-3558-36.3.411

Tan, S.W., Meiller, J.C., Mahaffey, K.R., 2009. The endocrine effects of mercury in humans and wildlife. Crit. Rev. Toxicol. 39, 228-269. https://doi.org/10.1080/10408440802233259

Thiers, L., Delord, K., Barbraud, C., Phillips, R.A., Pinaud, D., Weimerskirch, H., 2014. Foraging zones of the two sibling species of giant petrels in the Indian Ocean throughout the annual cycle : implication for their conservation 499, 233-248. https://doi.org/10.3354/meps10620

Thompson, D.R., Becker, P.H., Furness, R.W., 1993. Long-term changes in mercury in concentrations herring gulls Larus argentatus and common terns Sterna hirundo from the German North Sea coast. J. Appl. Ecol. 30, 316-320.

Thompson, D.R., Furness, R.W., 1989a. The chemical form of mercury stored in South Atlantic seabirds. Environ. Pollut. 60, 305-317.

Thompson, D.R., Furness, R.W., 1989b. Differences in the chemical form of mercury stored in South Atlantic seabirds. Environ. Pollut. 60, 305-317. https://doi.org/10.1016/02697491(89)90111-5

Thompson, D.R., Stewart, F.M., Furness, R.W., 1990. Using seabirds to monitor mercury in marine environments. The validity of conversion ratios for tissue comparisons. Mar. Pollut. Bull. 21, 339-342. https://doi.org/10.1016/0025-326X(90)90795-A

Wolfe, M.F., Schwarzbach, S., Sulaiman, R.A., 1998. Effects of mercury on wildlife: A comprehensive review. Environ. Toxicol. Chem. 17, 146-160. https://doi.org/10.1002/etc.5620170203 


\section{Supporting information}

\section{Mercury isotopes of key tissues document mercury metabolic processes in seabirds}

$\underline{\text { Marina Renedo }}^{1,2^{*}}$, Zoyne Pedrero ${ }^{2 *}$, David Amouroux ${ }^{2}$, Yves Cherel $^{3}$, Paco Bustamante ${ }^{1,4}$

${ }^{1}$ Littoral Environnement et Sociétés (LIENSs), UMR 7266 CNRS- La Rochelle Université, 2 rue Olympe de Gouges, 17000 La Rochelle, France

${ }^{2}$ Universite de Pau et des Pays de l'Adour, E2S UPPA, CNRS, IPREM, Institut des Sciences Analytiques et de Physico-chimie pour l'Environnement et les matériaux, Pau, France

${ }^{3}$ Centre d'Etudes Biologiques de Chizé, UMR 7372 du CNRS-La Rochelle Université, 79360 Villiers-en-Bois, France

${ }^{4}$ Institut Universitaire de France (IUF), 1 rue Descartes 75005 Paris, France

*Corresponding authors: marina.renedo@ird.fr; zoyne.pedrerozayas@univ-pau.fr 


\section{Hg isotopic composition analyses}

$\mathrm{Hg}$ isotopic compositions of samples are reported using delta notation according to the following equations:

$$
\left.\delta^{\mathrm{xxx}} \mathrm{Hg}=\left[\left({ }^{\mathrm{xxx} / 198} \mathrm{Hg}_{\text {sample }} /{ }^{\mathrm{xxx} / 198} \mathrm{Hg} \text { NIST } 3133\right)-1\right)\right] \cdot 1000(\%)
$$

MIF signatures are expressed using capital delta notation, as suggested elsewhere (Bergquist and Blum, 2007), according to the following equations:

$$
\begin{aligned}
& \Delta^{204} \mathrm{Hg}=\delta^{204} \mathrm{Hg}-\left(1.493 \cdot \delta^{202} \mathrm{Hg}\right) \\
& \Delta^{201} \mathrm{Hg}=\delta^{201} \mathrm{Hg}-\left(0.752 \cdot \delta^{202} \mathrm{Hg}\right) \\
& \Delta^{200} \mathrm{Hg}=\delta^{200} \mathrm{Hg}-\left(0.502 \cdot \delta^{202} \mathrm{Hg}\right) \\
& \Delta^{199} \mathrm{Hg}=\delta^{199} \mathrm{Hg}-\left(0.252 \cdot \delta^{202} \mathrm{Hg}\right)
\end{aligned}
$$




\section{Supplementary figures}

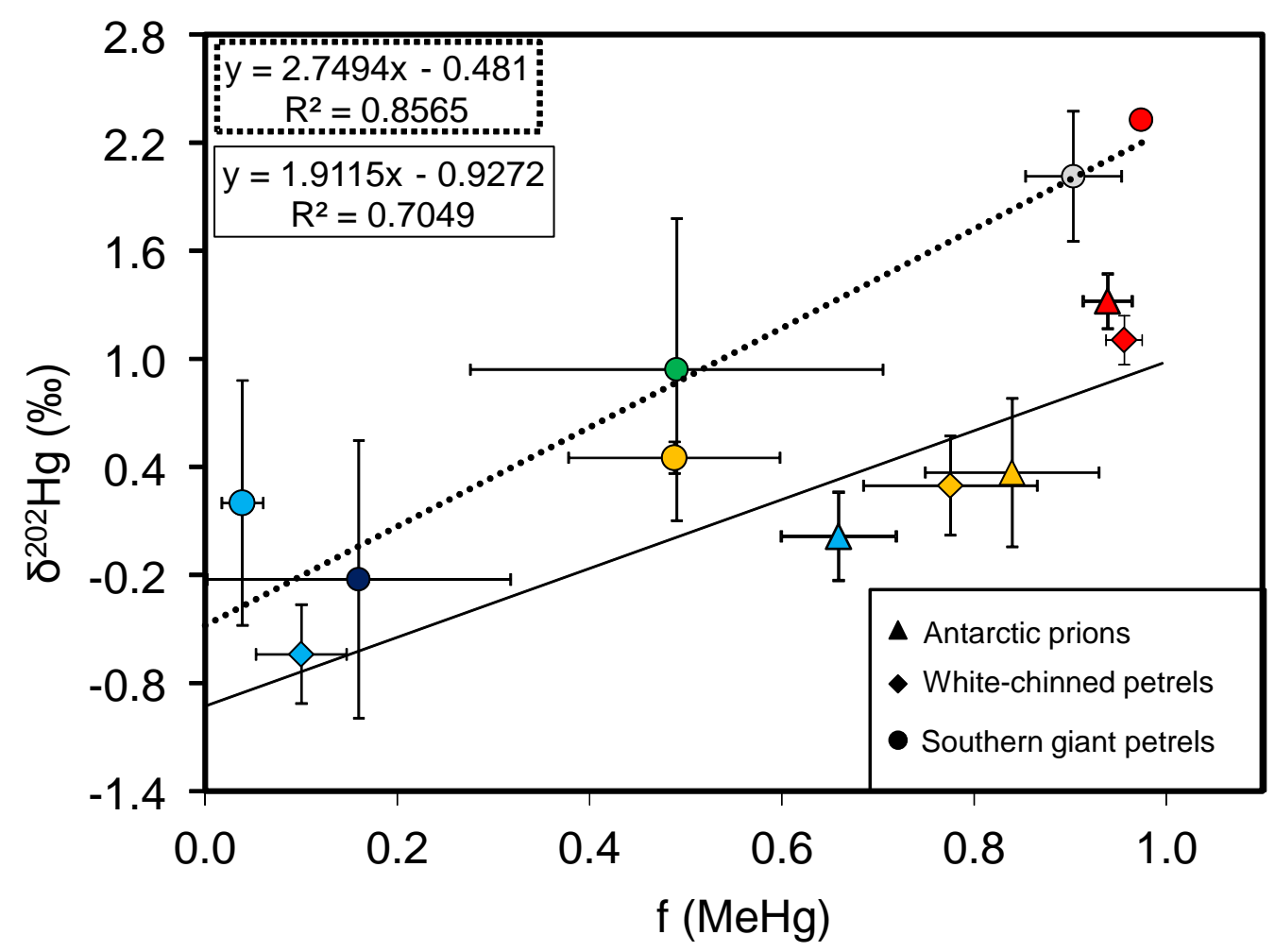

Figure S1. Hg MDF signatures (as $\delta^{202} \mathrm{Hg}$ ) relative to the percentage of $\mathrm{MeHg}$ for the three seabird species together. Mean values of feathers, muscles and livers of Antarctic prions $(n=10)$ and white-chinned petrels $(n=10)$ exhibited a regression line of $y=1.91 x-0.92$, Spearman correlation coefficients were $\mathrm{R}^{2}=0.70, \mathrm{p}<0.0001$; while the man values of tissues of giant petrels $(n=3)$ exhibited a regression line of $y=2.75 x-0.48$, Spearman correlation coefficients were $R^{2}=$ $0.85, \mathrm{p}<0.0001$. Highlighted symbols with error bars represent mean \pm SD values for each tissue. 


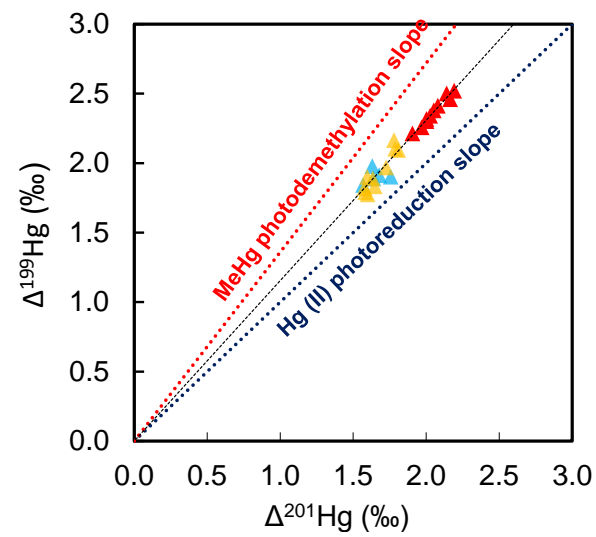

\section{Antarctic prions}

\begin{tabular}{|l|}
\hline$\Delta$ Liver \\
$\Delta$ Muscle \\
$\Delta$ Feathers
\end{tabular}

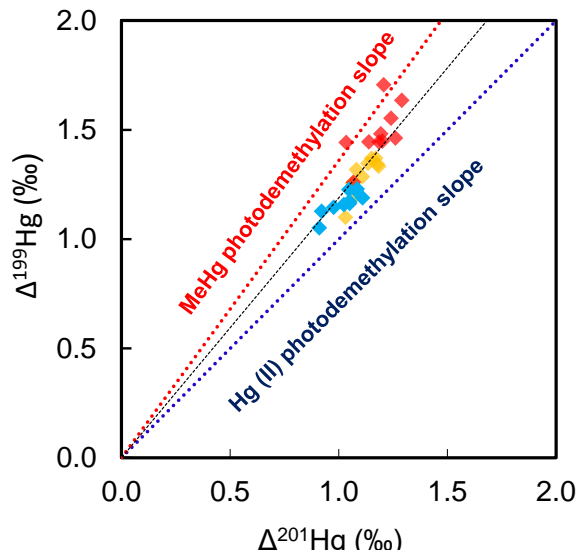

White-chinned petrels

\begin{tabular}{l|}
$\diamond$ Liver \\
$\diamond$ Muscle \\
$\diamond$ Feathers
\end{tabular}

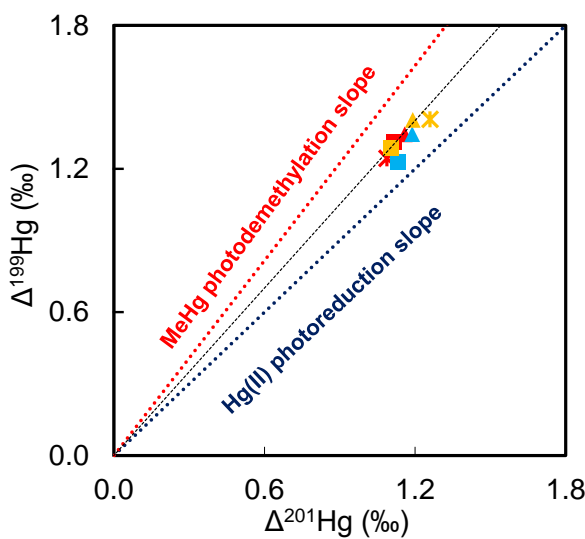

Southern giant petrels

\begin{tabular}{l|l}
- Liver & $\begin{array}{l}\text { M Juvenile } \\
\text { M Adult }\end{array}$ \\
\hline
\end{tabular}

- Feathers $\quad$ ald

Figure S2. Hg odd-MIF signatures $\left(\Delta^{199} \mathrm{Hg}\right.$ versus $\left.\Delta^{201} \mathrm{Hg}\right)$. The red and blue dashed lines represent the theoretical $\Delta^{199} \mathrm{Hg} / \Delta^{201} \mathrm{Hg}$ slope for $\mathrm{MeHg}$ photodemethylation and for $\mathrm{Hg}$ (II) photoreduction in the water column (Bergquist and Blum, 2007). $\Delta^{199} \mathrm{Hg} / \Delta^{201} \mathrm{Hg}$ slope for Antarctic prions was $1.16 \pm 0.05$ (SE), intercept $=-0.01 \pm 0.09(\mathrm{SE}), \mathrm{R}^{2}=0.96, \mathrm{p}<0.0001$; whitechinned petrel slope is $1.19 \pm 0.12(\mathrm{SE}), \mathrm{R}^{2}=0.70, \mathrm{p}<0.0001$. For the southern giant petrel samples $\Delta^{199} \mathrm{Hg} / \Delta^{201} \mathrm{Hg}$ line regression is of $1.06 \pm 0.19(\mathrm{SE}), \mathrm{R}^{2}=0.70, \mathrm{p}=0.0001$. 
Table S1. Mean values of $\mathrm{Hg}$ species concentration (ng. $\mathrm{g}^{-1}$, dw) obtained for reference materials: DOLT-4 (CRM dogfish liver), ERM-CE-464 (CRM tuna fish) and NIES-13 (CRM human hair). $\mathrm{N}$ means number of extractions (triplicate of extraction and triplicate of analyses).

\begin{tabular}{|c|c|c|c|c|c|c|c|}
\hline Sample & Reference & n & $\begin{array}{c}\text { Hg(II) } \\
\left(\mathbf{n g} \cdot \mathbf{g}^{-1}\right) \\
\text { Mean } \pm \text { SD }\end{array}$ & $\begin{array}{r}\text { MeHg } \\
\left(\mathbf{n g} \cdot \mathbf{g}^{-1}\right)\end{array}$ & $\begin{array}{c}\text { Recovery } \\
\text { MeHg } \\
(\%)\end{array}$ & $\begin{array}{c}\text { THg } \\
\left(\mathbf{n g} \cdot \mathbf{g}^{-1}\right) \\
\text { Mean } \pm \text { SD }\end{array}$ & $\begin{array}{c}\text { Recovery } \\
\text { THg } \\
(\%)\end{array}$ \\
\hline DOLT-4 & $\begin{array}{l}\text { Certified } \\
\text { values } \\
\text { Obtained } \\
\text { values }\end{array}$ & 3 & $1342 \pm 77$ & $1330 \pm 120$ & $92.4 \pm 4.5$ & $\begin{array}{c}2580 \pm 220 \\
2570 \pm 97\end{array}$ & $99.6 \pm 3.8$ \\
\hline $\begin{array}{c}\text { ERM-CE- } \\
464\end{array}$ & $\begin{array}{l}\text { Certified } \\
\text { values } \\
\text { Obtained } \\
\text { values }\end{array}$ & 3 & $266 \pm 24$ & $5117 \pm 158$ & $97.0 \pm 0.9$ & $5240 \pm 100$ & $99.8 \pm 1.0$ \\
\hline NIES-13 & $\begin{array}{l}\text { Certified } \\
\text { values } \\
\text { Obtained } \\
\text { values }\end{array}$ & 3 & $792 \pm 78$ & $3800 \pm 400$ & $94.2 \pm 1.8$ & $4420 \pm 200$ & $97.7 \pm 1.5$ \\
\hline
\end{tabular}


Table S2. Mean values of Hg isotopic composition obtained for reference materials: UM-Almadén (CRM cinnabar), DOLT-4 (CRM dogfish liver), ERM-CE464 (CRM tuna fish), NIES-13 (CRM human hair), IAEA-086 (RM human hair), P-KP (IRM penguin feathers) and RBC-KP (IRM penguin red blood cells).

\begin{tabular}{|c|c|c|c|c|c|c|c|c|c|c|c|c|c|c|c|c|c|c|c|c|}
\hline Sample & Reference & $\mathbf{n}$ & $\begin{array}{c}\boldsymbol{\delta}^{204} \mathbf{H g} \\
\%\end{array}$ & $\begin{array}{c}\text { 2SD } \\
\%\end{array}$ & $\begin{array}{c}\boldsymbol{\delta}^{202} \mathrm{Hg} \\
\%\end{array}$ & $\begin{array}{l}\text { 2SD } \\
\%\end{array}$ & $\begin{array}{c}\boldsymbol{\delta}^{\mathbf{2 0 1}} \mathbf{H g} \\
\% 0\end{array}$ & $\begin{array}{l}\text { 2SD } \\
\% 0\end{array}$ & $\begin{array}{c}\boldsymbol{\delta}^{200} \mathrm{Hg} \\
\%\end{array}$ & $\begin{array}{c}\text { 2SD } \\
\% 0\end{array}$ & $\begin{array}{c}\boldsymbol{\delta}^{\mathbf{1 9 9}} \mathbf{H g} \\
\%\end{array}$ & $\begin{array}{c}\text { 2SD } \\
\% 0\end{array}$ & $\begin{array}{c}\Delta^{204} \mathbf{H g} \\
\%\end{array}$ & $\begin{array}{c}\text { 2SD } \\
\%\end{array}$ & $\begin{array}{c}\Delta_{\%}^{201} \mathbf{H g} \\
\% 0\end{array}$ & $\begin{array}{c}\text { 2SD } \\
\%\end{array}$ & $\begin{array}{c}\Delta^{200} \mathrm{Hg} \\
\%\end{array}$ & $\begin{array}{c}\text { 2SD } \\
\% 0\end{array}$ & $\begin{array}{c}\Delta_{\%}^{199} \mathbf{H g} \\
\%\end{array}$ & $\begin{array}{c}\text { 2SD } \\
\% 0\end{array}$ \\
\hline \multirow[t]{2}{*}{$\begin{array}{l}\text { NIST RM } 8610 \\
\text { UM Almadén }\end{array}$} & This study & 45 & -0.81 & 0.25 & -0.54 & 0.17 & -0.44 & 0.14 & -0.26 & 0.13 & -0.17 & 0.10 & -0.01 & 0.15 & -0.04 & 0.07 & 0.01 & 0.08 & -0.03 & 0.09 \\
\hline & $\begin{array}{l}\text { Reference } \\
\text { values }\end{array}$ & 61 & -0.82 & 0.07 & -0.56 & 0.03 & -0.46 & 0.02 & -0.27 & 0.01 & -0.17 & 0.01 & - & - & -0.04 & 0.01 & 0.00 & 0.01 & -0.03 & 0.02 \\
\hline \multirow[t]{2}{*}{ DOLT-4 } & This study & 2 & -0.50 & 0.08 & -0.33 & 0.07 & 0.66 & 0.03 & -0.13 & 0.10 & 1.01 & 0.04 & -0.01 & 0.02 & 0.91 & 0.02 & 0.04 & 0.06 & 1.09 & 0.02 \\
\hline & $\begin{array}{l}\text { Masbou et } \\
\text { al., } 2015\end{array}$ & 4 & - & & -0.35 & 0.20 & 0.71 & 0.06 & -0.14 & 0.06 & 1.03 & 0.07 & - & - & 0.98 & 0.19 & 0.02 & 0.03 & 1.12 & 0.11 \\
\hline \multirow[t]{2}{*}{ ERM-CE-464 } & This study & 2 & 0.91 & 0.13 & 0.64 & 0.04 & 2.37 & 0.03 & 0.40 & 0.00 & 2.49 & 0.01 & -0.04 & 0.19 & 1.89 & 0.05 & 0.08 & 0.01 & 2.33 & 0.01 \\
\hline & $\begin{array}{c}\text { Li et al., } \\
2014\end{array}$ & 9 & 0.94 & 0.06 & 0.70 & 0.04 & 2.49 & 0.06 & 0.43 & 0.05 & 2.55 & 0.08 & - & - & 1.96 & 0.06 & 0.07 & 0.04 & 2.38 & 0.07 \\
\hline \multirow[t]{2}{*}{ NIES-13 } & This study & 1 & 2.98 & - & 2.07 & - & 3.07 & - & 1.10 & - & 2.29 & - & -0.11 & - & 1.51 & - & 0.06 & - & 1.76 & - \\
\hline & $\begin{array}{l}\text { Yamakawa } \\
\text { et al., } 2016\end{array}$ & 11 & 2.76 & 0.16 & 1.89 & 0.10 & 2.77 & 0.10 & 0.98 & 0.08 & 2.13 & 0.07 & -0.04 & 0.11 & 1.36 & 0.07 & 0.04 & 0.04 & 1.65 & 0.06 \\
\hline \multirow[t]{2}{*}{ IAEA-086 } & This study & 1 & 1.23 & - & 0.81 & - & 0.76 & - & 0.45 & - & 0.50 & - & 0.02 & - & 0.15 & - & 0.04 & - & 0.29 & - \\
\hline & $\begin{array}{l}\text { Yamakawa } \\
\text { et al., } 2016\end{array}$ & 3 & 0.87 & 0.12 & 0.58 & 0.09 & 0.64 & 0.09 & 0.31 & 0.04 & 0.41 & 0.02 & 0.00 & 0.04 & 0.20 & 0.03 & 0.02 & 0.04 & 0.26 & 0.02 \\
\hline F-KP & This study & 3 & 2.35 & 0.15 & 1.52 & 0.12 & 2.65 & 0.06 & 0.76 & 0.07 & 2.12 & 0.04 & 0.09 & 0.16 & 1.51 & 0.07 & 0.00 & 0.07 & 1.74 & 0.05 \\
\hline RBC-KP & This study & 3 & 1.95 & 0.10 & 1.32 & 0.10 & 2.28 & 0.04 & 0.65 & 0.03 & 1.80 & 0.04 & -0.01 & 0.15 & 1.28 & 0.11 & -0.01 & 0.03 & 1.47 & 0.02 \\
\hline
\end{tabular}


Table S3. THg, $\mathrm{Hg}$ speciation ( $\mathrm{Hg}(\mathrm{II}), \mathrm{MeHg})$, and $\mathrm{Hg}$ isotopic composition $\left(\delta^{202} \mathrm{Hg}, \Delta^{199} \mathrm{Hg}\right)$ in Antarctic prions from Kerguelen Islands. Values not sharing the same superscript letter are significantly different. Values are means \pm SD. N1 means number of individuals for THg concentrations and $\mathrm{Hg}$ speciation. $\mathrm{N} 2$ means number of individuals for $\mathrm{Hg}$ isotopic analyses.

\begin{tabular}{|c|c|c|c|c|c|c|c|c|c|}
\hline \multirow[t]{2}{*}{ Tissue } & \multirow[t]{2}{*}{$\begin{array}{l}\mathbf{n} \\
\mathbf{1}\end{array}$} & \multirow{2}{*}{$\begin{array}{c}\text { THg } \\
\mu \mathrm{g} \mathrm{g}^{-1}\end{array}$} & \multirow{2}{*}{$\begin{array}{l}\mathbf{H g}(\mathbf{I I}) \\
\mu \mathrm{g} \mathrm{g}^{-1}\end{array}$} & \multicolumn{2}{|c|}{ MeHg } & \multirow[t]{2}{*}{$\begin{array}{l}\mathbf{n} \\
\mathbf{2}\end{array}$} & \multirow{2}{*}{$\begin{array}{c}\boldsymbol{\delta}^{202} \mathbf{H g} \\
\% 0\end{array}$} & \multirow{2}{*}{$\begin{array}{c}\Delta^{199} \mathbf{H g} \\
\% \text { o }\end{array}$} & \multirow{2}{*}{$\begin{array}{c}\Delta^{199} \mathbf{H g} / \Delta^{201} \mathbf{H} \\
\mathbf{g} \\
\text { ratio }\end{array}$} \\
\hline & & & & $\mu \mathrm{g} \mathrm{g}^{-1}$ & $\%$ & & & & \\
\hline Liver & 10 & $2.1 \pm 0.5^{\mathrm{A}}$ & $\begin{array}{c}0.71 \pm \\
0.02^{\mathrm{A}}\end{array}$ & $\begin{array}{l}1.4 \pm \\
0.4^{\mathrm{A}}\end{array}$ & $\begin{array}{c}66 \pm \\
6^{\mathrm{A}}\end{array}$ & 5 & $0.01 \pm \underset{\mathrm{A}}{ \pm} 0.25$ & $1.90 \pm \underset{\mathrm{A}}{ \pm} 0.05$ & $1.15 \pm 0.05^{\mathrm{A}}$ \\
\hline Muscle & 10 & $0.3 \pm 0.1^{\mathrm{B}}$ & $\begin{array}{c}0.05 \pm \\
0.02^{\mathrm{B}}\end{array}$ & $\begin{array}{l}0.3^{ \pm} \\
0.1^{\mathrm{B}}\end{array}$ & $84 \pm 5^{\text {B }}$ & 10 & $0.37 \underset{\mathrm{A}}{ \pm 0.41}$ & $1.93 \underset{\mathrm{A}}{ \pm 0.14}$ & $1.16 \pm 0.03^{\mathrm{A}}$ \\
\hline $\begin{array}{c}\text { Feather } \\
\mathrm{s}\end{array}$ & 10 & $2.6 \pm \underset{A}{0} 0.9$ & $\begin{array}{l}0.15 \pm \\
0.07^{\mathrm{C}}\end{array}$ & $\begin{array}{l}2.4 \pm \\
0.9^{\mathrm{C}}\end{array}$ & $94 \pm 3^{C}$ & 10 & $1.32 \underset{\mathrm{B}}{ \pm 0.13}$ & $2.37 \underset{\mathrm{B}}{ \pm} 0.10$ & $1.15 \pm 0.01^{\mathrm{A}}$ \\
\hline Blood & 9 & $0.7 \pm 0.1^{\mathrm{C}}$ & $\begin{array}{l}0.06 \pm \\
0.03^{\mathrm{B}}\end{array}$ & $\begin{array}{l}0.6 \pm \\
0.1^{\mathrm{D}}\end{array}$ & $90 \pm 3^{\mathrm{B}}$ & & NA & NA & NA \\
\hline Kidney & 10 & $0.9 \pm 0.2^{\mathrm{D}}$ & $\begin{array}{c}0.34 \pm \\
0.11^{\mathrm{D}}\end{array}$ & $\begin{array}{l}0.5 \pm \\
0.1^{\mathrm{D}}\end{array}$ & $\begin{array}{c}62 \pm \\
7^{\mathrm{A}}\end{array}$ & & NA & NA & NA \\
\hline
\end{tabular}

Table S4. THg, $\mathrm{Hg}$ speciation ( $\mathrm{Hg}(\mathrm{II}), \mathrm{MeHg})$ and $\mathrm{Hg}$ isotopic composition $\left(\delta^{202} \mathrm{Hg}, \Delta^{199} \mathrm{Hg}\right)$ in white-chinned petrels from Kerguelen Islands. Values not sharing the same superscript letter are significantly different. Values are means \pm SD.

\begin{tabular}{|c|c|c|c|c|c|c|c|c|}
\hline \multirow[t]{2}{*}{ Tissue } & \multirow[t]{2}{*}{$\mathbf{n}$} & \multirow{2}{*}{$\begin{array}{c}\text { THg } \\
\mu \mathrm{g} \mathrm{g}^{-1}\end{array}$} & \multirow{2}{*}{$\begin{array}{l}\mathbf{H g}(\mathbf{I I}) \\
\mu \mathrm{g} \mathrm{g}^{-1}\end{array}$} & \multicolumn{2}{|c|}{ MeHg } & \multirow{2}{*}{$\begin{array}{c}\boldsymbol{\delta}^{202} \mathbf{H g} \\
\%\end{array}$} & \multirow{2}{*}{$\begin{array}{c}\Delta^{199} \mathbf{H g} \\
\% 0\end{array}$} & \multirow{2}{*}{$\begin{array}{c}\Delta^{199} \mathbf{H g} / \Delta^{201} \mathbf{H g} \\
\text { ratio }\end{array}$} \\
\hline & & & & $\mu \mathrm{g} \mathrm{g}^{-1}$ & $\%$ & & & \\
\hline Liver & 10 & $54.3 \pm 18.7^{\mathrm{A}}$ & $49.4 \pm 18.8^{\mathrm{A}}$ & $4.9 \pm 2.1^{\mathrm{A}}$ & $10 \pm 5^{\mathrm{A}}$ & $-0.64 \pm 0.27^{\mathrm{A}}$ & $1.17 \pm 0.05^{\mathrm{A}}$ & $1.14 \pm 0.04^{\mathrm{A}}$ \\
\hline Muscle & 10 & $4.7 \pm 1.8^{\mathrm{B}}$ & $1.0 \pm 0.3^{\mathrm{B}}$ & $3.7 \pm 1.8^{\mathrm{A}}$ & $77 \pm 9^{\mathrm{B}}$ & $0.30 \pm 0.28^{\mathrm{B}}$ & $1.29 \pm 0.07^{\mathrm{B}}$ & $1.15 \pm 0.04^{\mathrm{A}}$ \\
\hline Feathers & 10 & $5.4 \pm 2.2^{\text {B }}$ & $0.2 \pm 0.1^{\mathrm{C}}$ & $5.2 \pm 2.1^{\mathrm{A}}$ & $96 \pm 2^{\mathrm{C}}$ & $1.10 \pm 0.14^{\mathrm{C}}$ & $1.49 \pm 0.21^{\mathrm{C}}$ & $1.26 \pm 0.08^{\text {В }}$ \\
\hline
\end{tabular}


Table S5. THg, $\mathrm{Hg}$ speciation ( $\mathrm{Hg}(\mathrm{II}), \mathrm{MeHg})$, and $\mathrm{Hg}$ isotopic composition $\left(\delta^{202} \mathrm{Hg}, \Delta^{199} \mathrm{Hg}\right)$ in southern giant petrels. Values are means \pm SD for triplicate analyses of the same sample.

\begin{tabular}{|c|c|c|c|c|c|c|c|}
\hline \multirow[t]{2}{*}{ Individual } & \multirow[t]{2}{*}{ Sample } & \multirow{2}{*}{$\begin{array}{c}\mathbf{T H g} \pm \text { SD } \\
\left(\mu \mathrm{g} \mathrm{g}^{-1}\right)\end{array}$} & \multirow{2}{*}{$\begin{array}{c}\mathbf{H g}(\mathbf{I I}) \pm \mathbf{S D} \\
\left(\mu \mathrm{g} \mathrm{g}^{-1}\right)\end{array}$} & \multicolumn{2}{|c|}{$\mathrm{MeHg} \pm \mathrm{SD}$} & \multirow{2}{*}{$\begin{array}{c}\delta^{202} \mathbf{H g} \\
\%\end{array}$} & \multirow{2}{*}{$\begin{array}{c}\Delta^{199} \mathbf{H g} \\
\%\end{array}$} \\
\hline & & & & $\left(\mu \mathrm{g} \mathrm{g}^{-1}\right)$ & $\%$ & & \\
\hline \multirow{6}{*}{$\begin{array}{c}\text { Individual } 1 \\
\text { (juvenile) }\end{array}$} & Liver & $214.2 \pm 34.2$ & $209.1 \pm 34.2$ & $5.1 \pm 0.8$ & $3 \pm 1$ & -0.28 & 1.34 \\
\hline & Kidney & $27.5 \pm 0.4$ & $24.8 \pm 0.4$ & $2.7 \pm 0.1$ & $10 \pm 1$ & -0.35 & 1.30 \\
\hline & Blood & $3.0 \pm 0.1$ & $0.31 \pm 0.01$ & $2.7 \pm 0.1$ & $90 \pm 1$ & 2.13 & 1.52 \\
\hline & Muscle & $4.1 \pm 0.1$ & $2.03 \pm 0.14$ & $2.1 \pm 0.1$ & $51 \pm 2$ & 0.38 & 1.41 \\
\hline & Feathers & $8.5 \pm 0.1$ & $0.21 \pm 0.01$ & $8.3 \pm 0.1$ & $97 \pm 3$ & 2.31 & 1.34 \\
\hline & Brain & $2.8 \pm 0.2$ & $1.70 \pm 0.16$ & $1.1 \pm 0.1$ & $40 \pm 3$ & 0.95 & 1.42 \\
\hline \multirow{6}{*}{$\begin{array}{l}\text { Individual } 2 \\
\text { (medium age) }\end{array}$} & Liver & NA & NA & NA & NA & NA & NA \\
\hline & Kidney & $39.9 \pm 0.4$ & $38.2 \pm 0.4$ & $1.6 \pm 0.1$ & $4 \pm 1$ & -0.93 & 1.36 \\
\hline & Blood & $3.0 \pm 0.1$ & $0.4 \pm 0.1$ & $2.6 \pm 0.1$ & $86 \pm 1$ & 1.61 & 1.34 \\
\hline & Muscle & $1.7 \pm 0.1$ & $0.7 \pm 0.1$ & $1,0 \pm 0.1$ & $58 \pm 3$ & 0.43 & 1.40 \\
\hline & Feathers & $10.3 \pm 0.1$ & $0.3 \pm 0.1$ & $10.0 \pm 0.1$ & $97 \pm 2$ & 2.32 & 1.24 \\
\hline & Brain & $1.6 \pm 0.1$ & $0.4 \pm 0.1$ & $1.16 \pm 0.01$ & $74 \pm 1$ & 1.77 & 1.34 \\
\hline \multirow{6}{*}{$\begin{array}{c}\text { Individual } 3 \\
\text { (senior) }\end{array}$} & Liver & $405.2 \pm 6.6$ & $381.7 \pm 6.6$ & $23.5 \pm 0.1$ & $6 \pm 1$ & 0.68 & 1.23 \\
\hline & Kidney & $50.8 \pm 0.7$ & $33.6 \pm 0.4$ & $17.2 \pm 0.5$ & $34 \pm 1$ & 0.60 & 1.46 \\
\hline & Blood & $23.9 \pm 0.1$ & $1.0 \pm 0.1$ & $22.9 \pm 0.1$ & $96 \pm 1$ & 2.30 & 1.57 \\
\hline & Muscle & $29.2 \pm 0.3$ & $18.5 \pm 0.2$ & $10.7 \pm 0.2$ & $37 \pm 1$ & 0.55 & 1.28 \\
\hline & Feathers & $21.2 \pm 0.1$ & $0.5 \pm 0.1$ & $20.6 \pm 0.1$ & $97 \pm 2$ & 2.35 & 1.31 \\
\hline & Brain & $13.2 \pm 0.2$ & $8.8 \pm 0.2$ & $4.4 \pm 0.1$ & $34 \pm 1$ & 0.10 & 1.41 \\
\hline
\end{tabular}


Table S6. Individual $\mathrm{MeHg}, \mathrm{Hg}(\mathrm{II})$ and $\mathrm{THg}$ concentrations ( $\mu \mathrm{g} \mathrm{g}^{-1} \mathrm{dw}$ ) and $\mathrm{Hg}$ isotopic composition of tissues Antarctic prions ( $\left.\mathrm{n}=10\right)$ from Kerguelen Islands. Values of THg and $\mathrm{Hg}$ species concentrations are expressed as mean \pm SD for triplicate of analyses.

\begin{tabular}{|c|c|c|c|c|c|c|c|c|c|c|c|c|c|}
\hline Sample & Tissue & $\begin{array}{l}\text { MeHg } \\
\mu \mathrm{g} \mathrm{g}^{-1}\end{array}$ & $\begin{array}{c}\mathbf{H g}(\mathbf{I I}) \\
\mu \mathrm{g} \mathrm{g}^{-1}\end{array}$ & $\begin{array}{r}\text { THg } \\
\mu \mathrm{g} \mathrm{g}^{-1}\end{array}$ & $\begin{array}{c}\boldsymbol{\delta}^{204} \mathbf{H g} \\
\% \text { o }\end{array}$ & $\begin{array}{c}\boldsymbol{\delta}^{202} \mathbf{H g} \\
\% 0\end{array}$ & $\begin{array}{c}\boldsymbol{\delta}^{201} \mathbf{H g} \\
\% 0\end{array}$ & $\begin{array}{c}\boldsymbol{\delta}^{200} \mathrm{Hg} \\
\% 0\end{array}$ & $\begin{array}{c}\delta^{199} \mathrm{Hg} \\
\% 0\end{array}$ & $\begin{array}{c}\Delta^{204} \mathrm{Hg} \\
\% 0\end{array}$ & $\begin{array}{c}\Delta^{201} \mathrm{Hg} \\
\% 0\end{array}$ & $\begin{array}{c}\Delta^{200} \mathrm{Hg} \\
\% \text { o }\end{array}$ & $\begin{array}{c}\Delta^{199} \mathbf{H g} \\
\% о\end{array}$ \\
\hline FA01-LivA & Liver & $1.94 \pm 0.22$ & $1.00 \pm 0.09$ & $2.94 \pm 0.29$ & NA & NA & NA & NA & NA & NA & NA & NA & NA \\
\hline FA02-LivA & Liver & $1.32 \pm 0.05$ & $0.59 \pm 0.01$ & $1.89 \pm 0.02$ & NA & NA & NA & NA & NA & NA & NA & NA & NA \\
\hline FA03-LivA & Liver & $1.22 \pm 0.04$ & $0.66 \pm 0.01$ & $1.87 \pm 0.05$ & NA & NA & NA & NA & NA & NA & NA & NA & NA \\
\hline FA04-LivA & Liver & $0.95 \pm 0.04$ & $0.56 \pm 0.01$ & $1.50 \pm 0.05$ & NA & NA & NA & NA & NA & NA & NA & NA & NA \\
\hline FA05-LivA & Liver & $1.95 \pm 0.14$ & $0.73 \pm 0.11$ & $2.68 \pm 0.25$ & NA & NA & NA & NA & NA & NA & NA & $\mathrm{NA}$ & NA \\
\hline FA06-LivA & Liver & $0.89 \pm 0.16$ & $0.60 \pm 0.04$ & $1.49 \pm 0.14$ & -0.45 & -0.28 & 1.55 & -0.20 & -0.03 & 1.83 & 1.76 & -0.06 & 1.90 \\
\hline FA07-LivA & Liver & $1.13 \pm 0.02$ & $0.47 \pm 0.14$ & $1.60 \pm 0.11$ & 0.51 & 0.30 & 1.90 & 0.21 & 0.06 & 1.99 & 1.68 & 0.06 & 1.91 \\
\hline FA08-LivA & Liver & $1.25 \pm 0.12$ & $1.04 \pm 0.14$ & $2.30 \pm 0.26$ & -0.19 & -0.10 & 1.56 & -0.03 & -0.05 & 1.95 & 1.63 & 0.02 & 1.98 \\
\hline FA09-LivA & Liver & $1.65 \pm 0.23$ & $0.87 \pm 0.11$ & $2.52 \pm 0.24$ & -0.15 & -0.09 & 1.50 & -0.11 & -0.02 & 1.82 & 1.57 & -0.06 & 1.84 \\
\hline FA10-LivA & Liver & $1.55 \pm 0.17$ & $0.55 \pm 0.11$ & $2.10 \pm 0.20$ & 0.35 & 0.24 & 1.82 & 0.04 & 0.00 & 1.95 & 1.64 & -0.08 & 1.89 \\
\hline FA01-MusA & Muscle & $0.24 \pm 0.02$ & $0.027 \pm 0.0003$ & $0.28 \pm 0.02$ & 0.47 & 0.15 & 1.92 & 0.13 & 0.26 & 2.13 & 1.81 & 0.06 & 2.09 \\
\hline FA02-MusA & Muscle & $0.25 \pm 0.01$ & $0.028 \pm 0.002$ & $0.29 \pm 0.01$ & 0.07 & -0.10 & 1.65 & -0.03 & 0.21 & 1.94 & 1.72 & 0.02 & 1.97 \\
\hline FA03-MusA & Muscle & $0.18 \pm 0.00$ & $0.077 \pm 0.004$ & $0.26 \pm 0.01$ & -0.02 & 0.00 & 1.77 & 0.00 & -0.01 & 2.16 & 1.78 & 0.00 & 2.16 \\
\hline FA04-MusA & Muscle & $0.20 \pm 0.01$ & $0.031 \pm 0.001$ & $0.23 \pm 0.01$ & 0.99 & 0.57 & 2.02 & 0.22 & 0.15 & 2.04 & 1.60 & -0.07 & 1.90 \\
\hline FA05-MusA & Muscle & $0.35 \pm 0.01$ & $0.08 \pm 0.01$ & $0.43 \pm 0.01$ & 1.13 & 0.70 & 2.10 & 0.34 & 0.08 & 2.00 & 1.58 & -0.01 & 1.82 \\
\hline FA06-MusA & Muscle & $0.20 \pm 0.01$ & $0.033 \pm 0.002$ & $0.24 \pm 0.01$ & 1.09 & 0.79 & 2.38 & 0.43 & -0.08 & 2.30 & 1.79 & 0.04 & 2.10 \\
\hline FA07-MusA & Muscle & $0.22 \pm 0.01$ & $0.046 \pm 0.008$ & $0.27 \pm 0.01$ & 1.12 & 0.77 & 2.16 & 0.37 & -0.02 & 1.98 & 1.58 & -0.01 & 1.79 \\
\hline FA08-MusA & Muscle & $0.27 \pm 0.01$ & $0.042 \pm 0.003$ & $0.31 \pm 0.01$ & 1.34 & 0.89 & 2.32 & 0.44 & 0.02 & 2.06 & 1.65 & 0.00 & 1.83 \\
\hline FA09-MusA & Muscle & $0.29 \pm 0.01$ & $0.041 \pm 0.001$ & $0.33 \pm 0.01$ & -0.18 & -0.19 & 1.46 & -0.13 & 0.10 & 1.73 & 1.60 & -0.04 & 1.77 \\
\hline FA10-MusA & Muscle & $0.32 \pm 0.01$ & $0.068 \pm 0.003$ & $0.386 \pm 0.004$ & 0.25 & 0.12 & 1.73 & 0.01 & 0.06 & 1.92 & 1.63 & -0.05 & 1.89 \\
\hline FA01-pool-B1 & Feather & $1.98 \pm 0.01$ & $0.287 \pm 0.002$ & $2.27 \pm 0.02$ & 1.81 & 1.19 & 2.97 & 0.61 & 2.71 & 0.03 & 2.08 & 0.02 & 2.41 \\
\hline FA02-pool-B1 & Feather & $1.91 \pm 0.05$ & $0.15 \pm 0.01$ & $2.06 \pm 0.05$ & 2.27 & 1.55 & 3.22 & 0.77 & 2.77 & -0.04 & 2.05 & -0.01 & 2.38 \\
\hline FA03-pool-B1 & Feather & $3.09 \pm 0.04$ & $0.185 \pm 0.005$ & $3.28 \pm 0.04$ & 1.76 & 1.22 & 2.89 & 0.64 & 2.57 & -0.07 & 1.97 & 0.03 & 2.26 \\
\hline FA04-pool-B1 & Feather & $1.77 \pm 0.04$ & $0.09 \pm 0.01$ & $1.86 \pm 0.05$ & 2.08 & 1.41 & 3.09 & 0.75 & 2.70 & -0.02 & 2.03 & 0.04 & 2.34 \\
\hline FA05-pool-B1 & Feather & $1.94 \pm 0.03$ & $0.11 \pm 0.01$ & $2.05 \pm 0.03$ & 1.89 & 1.21 & 2.81 & 0.66 & 2.52 & 0.09 & 1.91 & 0.05 & 2.21 \\
\hline
\end{tabular}




\begin{tabular}{|c|c|c|c|c|c|c|c|c|c|c|c|c|c|}
\hline FA06-pool-B1 & Feather & $1.84 \pm 0.03$ & $0.11 \pm 0.01$ & $1.96 \pm 0.03$ & 2.22 & 1.51 & 3.33 & 0.80 & 2.90 & -0.04 & 2.19 & 0.04 & 2.52 \\
\hline FA07-pool-B1 & Feather & $3.24 \pm 0.09$ & $0.149 \pm 0.002$ & $3.39 \pm 0.09$ & 1.94 & 1.31 & 2.99 & 0.69 & 2.65 & -0.01 & 2.00 & 0.04 & 2.32 \\
\hline FA08-pool-B1 & Feather & $1.16 \pm 0.03$ & $0.06 \pm 0.01$ & $1.22 \pm 0.03$ & 1.92 & 1.24 & 3.07 & 0.66 & 2.81 & 0.08 & 2.14 & 0.04 & 2.50 \\
\hline FA09-pool-B1 & Feather & $3.84 \pm 0.05$ & $0.14 \pm 0.01$ & $3.98 \pm 0.06$ & 1.98 & 1.27 & 3.11 & 0.62 & 2.78 & 0.09 & 2.16 & -0.01 & 2.46 \\
\hline FA10-pool-B1 & Feather & $3.38 \pm 0.05$ & $0.233 \pm 0.005$ & $3.61 \pm 0.05$ & 2.08 & 1.29 & 2.97 & 0.67 & 2.63 & 0.15 & 2.00 & 0.02 & 2.30 \\
\hline FA01-KidA & Kidneys & 0.57 & 0.46 & 1.03 & NA & NA & NA & NA & NA & NA & NA & NA & NA \\
\hline FA02-KidA & Kidneys & 0.52 & 0.37 & 0.89 & NA & NA & NA & NA & NA & NA & NA & NA & NA \\
\hline FA03-KidA & Kidneys & 0.49 & 0.49 & 0.97 & NA & NA & NA & NA & NA & NA & NA & NA & NA \\
\hline FA04-KidA & Kidneys & 0.47 & 0.17 & 0.64 & NA & NA & NA & NA & NA & NA & NA & NA & NA \\
\hline FA05-KidA & Kidneys & 0.68 & 0.36 & 1.04 & NA & NA & NA & NA & NA & NA & NA & NA & NA \\
\hline FA06-KidA & Kidneys & 0.43 & 0.24 & 0.66 & NA & NA & NA & NA & NA & NA & NA & NA & NA \\
\hline FA07-KidA & Kidneys & 0.52 & 0.20 & 0.72 & NA & NA & NA & NA & NA & NA & NA & NA & NA \\
\hline FA08-KidA & Kidneys & 0.60 & 0.40 & 1.00 & NA & NA & NA & NA & NA & NA & NA & NA & NA \\
\hline FA09-KidA & Kidneys & 0.46 & 0.36 & 0.82 & NA & NA & NA & NA & NA & NA & NA & NA & NA \\
\hline FA10-KidA & Kidneys & 0.62 & 0.39 & 1.01 & NA & NA & NA & NA & NA & NA & NA & NA & NA \\
\hline FA01-Fat & Blood & NA & NA & NA & NA & NA & NA & NA & NA & NA & NA & NA & NA \\
\hline FA02-Fat & Blood & 0.72 & 0.04 & 0.76 & NA & NA & NA & NA & NA & NA & NA & NA & NA \\
\hline FA03-Fat & Blood & 0.47 & 0.05 & 0.52 & NA & NA & NA & NA & NA & NA & NA & NA & NA \\
\hline FA04-Fat & Blood & 0.50 & 0.04 & 0.54 & NA & NA & NA & NA & NA & NA & NA & NA & NA \\
\hline FA05-Fat & Blood & 0.69 & 0.10 & 0.79 & NA & NA & NA & NA & NA & NA & NA & NA & NA \\
\hline FA06-Fat & Blood & 0.48 & 0.09 & 0.57 & NA & NA & NA & NA & NA & NA & NA & NA & NA \\
\hline FA07-Fat & Blood & 0.52 & 0.04 & 0.56 & NA & NA & NA & NA & NA & NA & NA & NA & NA \\
\hline FA08-Fat & Blood & 0.73 & 0.06 & 0.79 & NA & NA & NA & NA & NA & NA & NA & NA & NA \\
\hline FA09-Fat & Blood & 0.56 & 0.10 & 0.66 & NA & NA & NA & NA & NA & NA & NA & NA & NA \\
\hline FA10-Fat & Blood & 0.67 & 0.07 & 0.75 & NA & NA & NA & NA & NA & NA & NA & NA & NA \\
\hline
\end{tabular}


Table S7. Individual values of $\mathrm{MeHg}, \mathrm{Hg}(\mathrm{II})$ and $\mathrm{THg}$ concentrations ( $\mu \mathrm{g} \mathrm{g}^{-1} \mathrm{dw}$ ) and $\mathrm{Hg}$ isotopic composition of tissues white-chinned petrels ( $\left.\mathrm{n}=10\right)$ from Kerguelen Islands. Values of THg and $\mathrm{Hg}$ species concentrations are expressed as mean \pm SD for triplicate of analyses.

\begin{tabular}{|c|c|c|c|c|c|c|c|c|c|c|c|c|c|}
\hline Species & Tissue & $\begin{array}{c}\text { MeHg } \\
\mu \mathrm{g} \mathrm{g}^{-1}\end{array}$ & $\begin{array}{c}\mathbf{H g}(\mathbf{I I}) \\
\mu \mathrm{g} \mathrm{g}^{-1}\end{array}$ & $\begin{array}{c}\text { THg } \\
\mu \mathrm{g} \mathrm{g}^{-1}\end{array}$ & $\begin{array}{c}\boldsymbol{\delta}^{\mathbf{2 0 4}} \mathbf{H g} \\
\% 0\end{array}$ & $\begin{array}{c}\boldsymbol{\delta}^{202} \mathrm{Hg} \\
\% 0\end{array}$ & $\begin{array}{c}\boldsymbol{\delta}^{201} \mathbf{H g} \\
\% 0\end{array}$ & $\begin{array}{c}\boldsymbol{\delta}^{200} \mathrm{Hg} \\
\% 0\end{array}$ & $\begin{array}{c}\boldsymbol{\delta}^{199} \mathbf{H g} \\
\% 0\end{array}$ & $\begin{array}{c}\Delta^{204} \mathrm{Hg} \\
\% 0\end{array}$ & $\begin{array}{c}\Delta^{201} \mathbf{H g} \\
\% 0\end{array}$ & $\begin{array}{c}\Delta^{200} \mathrm{Hg} \\
\% 0\end{array}$ & $\begin{array}{c}\Delta^{199} \mathrm{Hg} \\
\% 0\end{array}$ \\
\hline WCP01-LivA & Liver & $1.92 \pm 0.05$ & $57.90 \pm 0.71$ & $59.82 \pm 0.71$ & -1.34 & -0.91 & 0.36 & -0.45 & 1.00 & 0.03 & 1.05 & 0.01 & 1.23 \\
\hline WCP02-LivA & Liver & $1.73 \pm 0.06$ & $79.27 \pm 0.64$ & $81.00 \pm 0.64$ & -1.13 & -0.80 & 0.32 & -0.43 & 0.92 & 0.07 & 0.92 & -0.02 & 1.13 \\
\hline WCP03-LivA & Liver & $5.54 \pm 0.04$ & $69.36 \pm 0.68$ & $74.90 \pm 0.68$ & -1.21 & -0.80 & 0.42 & -0.40 & 0.96 & -0.01 & 1.02 & 0.00 & 1.16 \\
\hline WCP04-LivA & Liver & $4.36 \pm 0.09$ & $33.96 \pm 0.70$ & $38.32 \pm 0.71$ & -0.20 & -0.11 & 1.03 & -0.10 & 1.16 & -0.03 & 1.11 & -0.04 & 1.19 \\
\hline WCP05-LivA & Liver & $4.60 \pm 0.06$ & $41.34 \pm 0.45$ & $45.95 \pm 0.46$ & -0.65 & -0.45 & 0.71 & -0.27 & 1.05 & 0.02 & 1.05 & -0.04 & 1.16 \\
\hline WCP06-LivA & Liver & $7.95 \pm 0.20$ & $69.30 \pm 0.27$ & $77.26 \pm 0.33$ & -1.50 & -0.99 & 0.17 & -0.54 & 0.80 & -0.02 & 0.91 & -0.04 & 1.05 \\
\hline WCP07-LivA & Liver & $4.97 \pm 0.05$ & $27.98 \pm 0.54$ & $32.94 \pm 0.54$ & -1.08 & -0.76 & 0.51 & -0.38 & 1.03 & 0.05 & 1.08 & 0.00 & 1.22 \\
\hline WCP08-LivA & Liver & $8.15 \pm 0.06$ & $49.46 \pm 0.24$ & $57.62 \pm 0.25$ & -0.99 & -0.68 & 0.47 & -0.35 & 0.98 & 0.02 & 0.98 & -0.01 & 1.15 \\
\hline WCP09-LivA & Liver & $4.55 \pm 0.10$ & $40.29 \pm 0.29$ & $44.83 \pm 0.31$ & -0.83 & -0.54 & 0.68 & -0.26 & 1.09 & -0.02 & 1.08 & 0.01 & 1.23 \\
\hline WCP10-LivA & Liver & $5.01 \pm 0.03$ & $25.64 \pm 0.18$ & $30.65 \pm 0.18$ & -0.57 & -0.35 & 0.79 & -0.25 & 1.08 & -0.05 & 1.05 & -0.07 & 1.17 \\
\hline WCP01-MusA & Muscle & $1.67 \pm 0.13$ & $0.60 \pm 0.02$ & $2.27 \pm 0.13$ & -0.19 & -0.17 & 0.90 & -0.12 & 1.06 & 0.07 & 1.03 & -0.04 & 1.10 \\
\hline WCP02-MusA & Muscle & $1.33 \pm 0.01$ & $0.90 \pm 0.04$ & $2.23 \pm 0.04$ & -0.08 & -0.14 & 1.08 & -0.09 & 1.30 & 0.13 & 1.18 & -0.02 & 1.33 \\
\hline WCP03-MusA & Muscle & $4.27 \pm 0.02$ & $1.07 \pm 0.03$ & $5.34 \pm 0.03$ & 0.83 & 0.60 & 1.60 & 0.33 & 1.52 & -0.07 & 1.15 & 0.03 & 1.37 \\
\hline WCP04-MusA & Muscle & $3.37 \pm 0.13$ & $0.79 \pm 0.06$ & $4.17 \pm 0.14$ & 0.55 & 0.33 & 1.42 & 0.19 & 1.45 & 0.05 & 1.17 & 0.02 & 1.37 \\
\hline WCP05-MusA & Muscle & $4.15 \pm 0.06$ & $1.06 \pm 0.02$ & $5.21 \pm 0.06$ & 0.59 & 0.41 & 1.39 & 0.29 & 1.42 & -0.02 & 1.08 & 0.09 & 1.32 \\
\hline WCP06-MusA & Muscle & $4.75 \pm 0.11$ & $0.82 \pm 0.04$ & $5.57 \pm 0.12$ & 0.58 & 0.40 & 1.37 & 0.17 & 1.29 & -0.01 & 1.07 & -0.03 & 1.19 \\
\hline WCP07-MusA & Muscle & $4.07 \pm 0.09$ & $1.01 \pm 0.03$ & $5.08 \pm 0.10$ & 0.69 & 0.48 & 1.54 & 0.20 & 1.46 & -0.03 & 1.18 & -0.04 & 1.34 \\
\hline WCP08-MusA & Muscle & $6.15 \pm 0.06$ & $1.66 \pm 0.04$ & $7.81 \pm 0.07$ & 0.38 & 0.21 & 1.22 & 0.10 & 1.31 & 0.06 & 1.06 & -0.01 & 1.26 \\
\hline WCP09-MusA & Muscle & $3.60 \pm 0.02$ & $0.87 \pm 0.06$ & $4.46 \pm 0.06$ & 0.64 & 0.44 & 1.47 & 0.20 & 1.46 & -0.02 & 1.13 & -0.02 & 1.35 \\
\hline WCP10-MusA & Muscle & $3.70 \pm 0.11$ & $1.11 \pm 0.07$ & $4.81 \pm 0.13$ & 0.56 & 0.41 & 1.42 & 0.20 & 1.39 & -0.05 & 1.11 & -0.01 & 1.29 \\
\hline WCP01-pool-B1 & Feathers & $8.23 \pm 0.06$ & $0.28 \pm 0.01$ & $8.51 \pm 0.04$ & 1.41 & 0.95 & 1.86 & 0.52 & 1.69 & -0.01 & 1.14 & 0.05 & 1.45 \\
\hline
\end{tabular}




\begin{tabular}{|c|c|c|c|c|c|c|c|c|c|c|c|c|}
\hline WCP02-pool-B1 & Feathers & $3.45 \pm 0.02$ & $0.17 \pm 0.01$ & $3.62 \pm 0.02$ & 1.92 & 1.27 & 2.15 & 0.69 & 1.80 & 0.03 & 1.19 & 0.05 \\
\hline WCP03-pool-B1 & Feathers & $4.13 \pm 0.04$ & $0.017 \pm 0.001$ & $4.15 \pm 0.04$ & 1.77 & 1.22 & 2.10 & 0.64 & 1.75 & -0.05 & 1.19 & 0.02 \\
\hline WCP04-pool-B1 & Feathers & $3.95 \pm 0.03$ & $0.21 \pm 0.01$ & $4.17 \pm 0.03$ & 1.56 & 1.08 & 2.01 & 0.58 & 1.72 & -0.05 & 1.20 & 0.04 \\
\hline WCP05-pool-B1 & Feathers & $2.77 \pm 0.02$ & $0.24 \pm 0.02$ & $3.01 \pm 0.03$ & 1.30 & 0.91 & 1.97 & 0.48 & 1.86 & -0.06 & 1.29 & 0.02 \\
\hline WCP06-pool-B1 & Feathers & $3.94 \pm 0.02$ & $0.19 \pm 0.01$ & $4.13 \pm 0.02$ & 1.53 & 1.03 & 1.85 & 0.55 & 1.52 & -0.02 & 1.07 & 0.03 \\
\hline WCP07-pool-B1 & Feathers & $8.07 \pm 0.25$ & $0.47 \pm 0.01$ & $8.54 \pm 0.26$ & 1.56 & 1.03 & 2.01 & 0.60 & 1.81 & 0.03 & 1.24 & 0.09 \\
\hline WCP08-pool-B1 & Feathers & $6.21 \pm 0.02$ & $0.26 \pm 0.02$ & $6.48 \pm 0.02$ & 1.50 & 1.04 & 1.81 & 0.67 & 1.70 & -0.05 & 1.03 & 0.14 \\
\hline WCP09-pool-B1 & Feathers & $7.33 \pm 0.13$ & $0.37 \pm 0.03$ & $7.70 \pm 0.16$ & 1.80 & 1.20 & 2.11 & 0.73 & 2.01 & 0.01 & 1.21 & 0.13 \\
\hline WCP10-pool-B1 & Feathers & $3.37 \pm 0.06$ & $0.17 \pm 0.01$ & $3.54 \pm 0.06$ & 1.98 & 1.31 & 2.25 & 0.66 & 1.79 & 0.02 & 1.26 & 0.00 \\
\hline
\end{tabular}


Table S8. Individual values of $\mathrm{MeHg}, \mathrm{Hg}(\mathrm{II})$ and $\mathrm{THg}$ concentrations $\left(\mu \mathrm{g} \mathrm{g}^{-1} \mathrm{dw}\right), \mathrm{MeHg}$ proportion and $\mathrm{Hg}$ isotopic composition of tissues of southern giant petrels $(\mathrm{n}=3$ ) from Kerguelen Islands. PGA01 is the young specimen, PGA02 a medium age individual and PGA03 the oldest individual. Values of THg and Hg species concentrations are expressed as mean \pm SD for triplicate of analyses.

\begin{tabular}{|c|c|c|c|c|c|c|c|c|c|c|c|c|c|}
\hline Sample & Tissue & $\begin{array}{c}\mathrm{MeHg} \\
\mu \mathrm{g} \mathrm{g}^{-1}\end{array}$ & $\begin{array}{c}\mathbf{H g}(\mathbf{I I}) \\
\mu \mathrm{g} \mathrm{g}^{-1}\end{array}$ & $\begin{array}{r}\text { THg } \\
\mu \mathrm{g} \mathrm{g}^{-1}\end{array}$ & $\begin{array}{c}\boldsymbol{\delta}^{204} \mathbf{H g} \\
\% 0\end{array}$ & $\begin{array}{c}\boldsymbol{\delta}^{202} \mathbf{H g} \\
\% 0\end{array}$ & $\begin{array}{c}\boldsymbol{\delta}^{201} \mathbf{H g} \\
\% 0\end{array}$ & $\begin{array}{c}\delta^{200} \mathrm{Hg} \\
\%\end{array}$ & $\begin{array}{c}\boldsymbol{\delta}^{199} \mathrm{Hg} \\
\%\end{array}$ & $\begin{array}{c}\Delta^{204} \mathrm{Hg} \\
\% 0\end{array}$ & $\begin{array}{c}\Delta^{201} \mathrm{Hg} \\
\% 0\end{array}$ & $\begin{array}{c}\Delta^{200} \mathrm{Hg} \\
\% 0\end{array}$ & $\begin{array}{c}\Delta^{199} \mathrm{Hg} \\
\% 0\end{array}$ \\
\hline PGA01-LivA & Liver & $5.09 \pm 0.80$ & $209.14 \pm 34.22$ & $214.22 \pm 34.23$ & -0.44 & -0.28 & 0.98 & -0.14 & 1.27 & -0.02 & 1.19 & 0.00 & 1.34 \\
\hline PGA03-LivA & Liver & $23.50 \pm 0.10$ & $381.69 \pm 6.56$ & $405.19 \pm 6.57$ & 1.06 & 0.68 & 1.64 & 0.32 & 1.40 & 0.05 & 1.13 & -0.02 & 1.23 \\
\hline PGA01-KidA & Kidney & $2.73 \pm 0.12$ & $24.80 \pm 0.41$ & $27.53 \pm 0.43$ & -0.48 & -0.35 & 0.87 & -0.21 & 1.21 & 0.04 & 1.13 & -0.03 & 1.30 \\
\hline PGA02-KidA & Kidney & $1.64 \pm 0.11$ & $38.23 \pm 0.43$ & $39.88 \pm 0.44$ & -1.63 & -0.93 & 0.40 & -0.44 & 1.13 & -0.24 & 1.10 & 0.03 & 1.36 \\
\hline PGA03-KidA & Kidney & $17.24 \pm 0.53$ & $33.60 \pm 0.40$ & $50.84 \pm 0.67$ & 0.77 & 0.60 & 1.63 & 0.28 & 1.61 & -0.12 & 1.18 & -0.03 & 1.46 \\
\hline PGA01-PGAt & Blood & $2.66 \pm 0.01$ & $0.31 \pm 0.01$ & $2.97 \pm 0.01$ & 3.25 & 2.13 & 2.86 & 1.06 & 2.06 & 0.08 & 1.26 & 0.00 & 1.52 \\
\hline PGA02-PGAt & Blood & $2.59 \pm 0.05$ & $0.431 \pm 0.003$ & $3.03 \pm 0.05$ & 2.41 & 1.61 & 2.33 & 0.79 & 1.74 & 0.00 & 1.12 & -0.02 & 1.34 \\
\hline PGA03-PGAt & Blood & $22.89 \pm 0.12$ & $1.04 \pm 0.03$ & $23.93 \pm 0.13$ & 3.43 & 2.30 & 3.05 & 1.14 & 2.15 & -0.01 & 1.32 & -0.01 & 1.57 \\
\hline PGA01-MusA & Muscle & $2.09 \pm 0.01$ & $2.03 \pm 0.14$ & $4.11 \pm 0.14$ & 0.49 & 0.38 & 1.54 & 0.17 & 1.50 & -0.08 & 1.26 & -0.02 & 1.41 \\
\hline PGA02-MusA & Muscle & $0.97 \pm 0.10$ & $0.69 \pm 0.02$ & $1.66 \pm 0.10$ & 0.53 & 0.43 & 1.51 & 0.18 & 1.51 & -0.12 & 1.19 & -0.03 & 1.40 \\
\hline PGA03-MusA & Muscle & $10.71 \pm 0.24$ & $18.46 \pm 0.21$ & $29.18 \pm 0.32$ & 0.93 & 0.55 & 1.52 & 0.20 & 1.42 & 0.11 & 1.10 & -0.07 & 1.28 \\
\hline PGA01-pool-B1 & Feathers & $8.32 \pm 0.11$ & $0.21 \pm 0.01$ & $8.50 \pm 0.11$ & 3.46 & 2.31 & 2.90 & 1.19 & 1.93 & 0.01 & 1.16 & 0.03 & 1.34 \\
\hline PGA02-pool-B1 & Feathers & $9.99 \pm 0.15$ & $0.29 \pm 0.02$ & $10.30 \pm 0.13$ & 3.53 & 2.32 & 2.83 & 1.18 & 1.83 & 0.07 & 1.09 & 0.01 & 1.24 \\
\hline PGA03-pool-B1 & Feathers & $20.66 \pm 0.06$ & $0.55 \pm 0.02$ & $21.20 \pm 0.05$ & 3.51 & 2.35 & 2.89 & 1.19 & 1.90 & 0.00 & 1.12 & 0.01 & 1.31 \\
\hline PGA01-brain-B1 & Brain & $1.14 \pm 0.06$ & $1.70 \pm 0.16$ & $2.84 \pm 0.17$ & 1.47 & 0.95 & 1.91 & 0.49 & 1.66 & 0.05 & 1.20 & 0.01 & 1.42 \\
\hline PGA02-brain-B1 & Brain & $1.16 \pm 0.01$ & $0.42 \pm 0.01$ & $1.58 \pm 0.02$ & 2.60 & 1.77 & 2.45 & 0.84 & 1.79 & -0.05 & 1.10 & -0.05 & 1.34 \\
\hline PGA03-brain-B1 & Brain & $4.44 \pm 0.10$ & $8.79 \pm 0.20$ & $13.23 \pm 0.22$ & 0.15 & 0.10 & 1.35 & 0.02 & 1.43 & 0.01 & 1.28 & -0.02 & 1.41 \\
\hline
\end{tabular}




\section{Further discussion of $\mathrm{Hg}$ accumulation in giant petrels with different age status}

We observed an increase of $\mathrm{Hg}$ concentrations with age in internal tissues of giant petrels (Fig. S2A). For instance, the older individual presented twice higher liver $\mathrm{Hg}$ concentration (405 $\pm 7 \mu \mathrm{g} \cdot \mathrm{g}^{-1}, \mathrm{n}=3$ triplicate of analyses) compared to the immature one (214 $\pm 34 \mu \mathrm{g} \cdot \mathrm{g}^{-1}, \mathrm{n}=3$ triplicate of analyses). Kidneys were also highly concentrated and increasing $\mathrm{Hg}$ levels were also found with age $\left(27.5 \pm 0.4,39.9 \pm 0.4\right.$ and $50.8 \pm 0.7 \mu \mathrm{g} \cdot \mathrm{g}^{-}$ 1; respectively for the juvenile, medium-aged and old individuals). This reflects a continuous bioaccumulation of $\mathrm{Hg}$ over the lifetime in this seabird species likely due to its accumulation with Se as observed in marine mammals (Perrot et al., 2016; Masbou et al., 2018; Bolea-Fernandez et al., 2019; Li et al., 2020).

Variable trends of $\delta^{202} \mathrm{Hg}$ values were found in internal tissues between the juvenile and old individuals (Fig. S2B). A predominance of $\mathrm{Hg}$ (II) in livers of the two individuals (> 94\%) strongly suggests that hepatic MeHg demethylation does occur efficiently in this seabird species. However, the juvenile petrel exhibited a strong shift of $\delta^{202} \mathrm{Hg}$ values from the livers to the muscle $(0.38$ to $-0.28 \%$ ) whereas muscles and liver of the older individual exhibited similar $\delta^{202} \mathrm{Hg}$ signatures (0.55 and $0.68 \%$, respectively). In vivo $\mathrm{MeHg}$ demethylation is known to be quite dependent on individual maturity and also on the exposure to Hg (Wagemann et al., 1998; Wang et al., 2013). Therefore, we could suppose that the extent of detoxification mechanism was not the same in the old seabird individual as a result of its high bioaccumulation level during its lifetime. An enrichment on heavier isotopes in the liver with age was already observed in recent studies in whales, with a clear difference between juvenile and adult individuals in the order of $\sim 0.6 \%$ in beluga whales (Masbou et al., 2018) and $\sim 1 \%$ in long finned pilot whales (BoleaFernandez et al., 2019). In experimental conditions, a progressive increase of $\delta^{202} \mathrm{Hg}$ 
values in fish liver was associated to the redistribution of $\mathrm{Hg}(\mathrm{II})$ from the liver towards the other tissues (Feng et al., 2015). Due to the high amount of $\mathrm{Hg}(\mathrm{II})$ accumulated within the liver of the old individual, we could suppose an analogous process in this seabird, explaining both its isotopically heavier $\mathrm{Hg}$ fraction in liver and the high amount of $\mathrm{Hg}$ (II) in muscles $(63 \%)$ relative to the younger individuals (42-48 \%).

As observed for the liver, the kidneys of the juvenile individual exhibited both lower $\delta^{202} \mathrm{Hg}$ values (-0.35\%) and higher $\mathrm{Hg}(\mathrm{II})$ fraction $(90 \%)$ than the older individual $(0.60$ $\%$ and $66 \%$, respectively). Kidneys of the medium-age individual presented the lowest $\delta^{202} \mathrm{Hg}$ values (-0.93\%) and the highest $\mathrm{Hg}(\mathrm{II})$ fraction $(96 \%)$. Likewise, the heavier isotopes in kidneys of the old individual could be associated to redistribution of $\mathrm{Hg}$ (II) from kidneys towards the other tissues. Both the depleted $\delta^{202} \mathrm{Hg}$ signatures and large fractions of $\mathrm{Hg}(\mathrm{II})$ observed in the liver (and kidneys) of giant petrels may be indicative of significant $\mathrm{MeHg}$ hepatic (and possibly renal) demethylation in this species, as observed in other seabirds (Kim et al., 1996; Cipro et al., 2014). However, the different $\mathrm{Hg}$ isotopic trends of individuals at contrasted life stages show variable extent of intertissue remobilisation and $\mathrm{Hg}$ species- specific storage depending on the age and levels of Hg bioaccumulation.

Brains exhibited variable $\% \mathrm{MeHg}$ depending on the age. The oldest individual presented a relatively lower $\% \mathrm{MeHg}(34 \%)$ and lighter $\delta^{202} \mathrm{Hg}$ values of the total $\mathrm{Hg}$ fraction $(0.10$ $\%$ ). In contrast, the juvenile and medium-age petrels exhibited higher \% $\mathrm{MeHg}$ (40 and $74 \%$ ) and heavier $\delta^{202} \mathrm{Hg}$ values (0.95 and $1.77 \%$, respectively). Higher $\% \mathrm{MeHg}$ and enriched $\delta^{202} \mathrm{Hg}$ values in brains of juveniles compared to adults were also observed in whales (Li et al., 2020). MeHg is known to cross the blood-brain barrier (Clarkson and Magos, 2006; Bridges and Zalups, 2010) where it can accumulate and cause serious 
neurological damage for birds (Evers et al., 2008). Our Hg isotopic results could suggest the existence of potential demethylation of $\mathrm{MeHg}$ in brain and/or mobilisation of $\mathrm{Hg}$ (II) from liver into the brain, explaining isotopically lighter $\mathrm{Hg}(\mathrm{II})$ over their lifetime, as hypothesized in whales (Li et al., 2020).
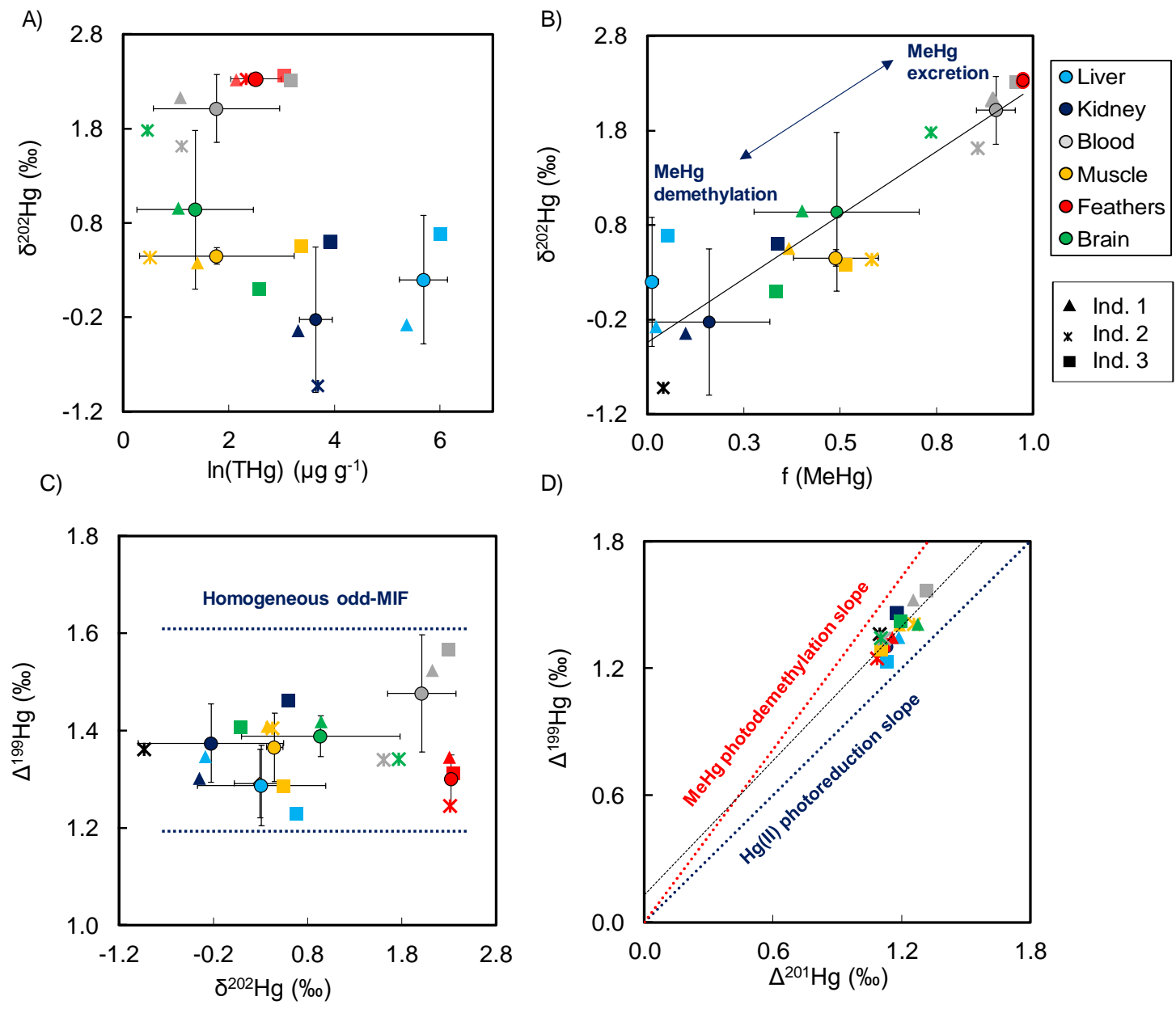

Figure S3. Southern giant petrels. A) $\mathrm{THg}$ concentrations and $\mathrm{Hg} \mathrm{MDF}$ (as $\delta^{202} \mathrm{Hg}$ ). B) $\mathrm{Hg} \mathrm{MDF}$ relative to the percentage of $\mathrm{MeHg}$ (regression line: $\mathrm{y}=2.75 \mathrm{x}-0.48$, Spearman correlation coefficients were $\mathrm{R}^{2}=0.92, \mathrm{p}<0.0001$ ). C) $\mathrm{Hg}$ MDF versus $\mathrm{Hg}$ odd-MIF (expressed as $\delta^{202} \mathrm{Hg}$ and $\Delta^{199} \mathrm{Hg}$, respectively) D) $\mathrm{Hg}$ odd-MIF signatures $\left(\Delta^{199} \mathrm{Hg}\right.$ versus $\Delta^{201} \mathrm{Hg}$ ). The red and blue dashed line represents the theoretical $\Delta^{199} \mathrm{Hg} / \Delta^{201} \mathrm{Hg}$ slope for MeHg photodemethylation and for photoreduction of $\mathrm{Hg}(\mathrm{II})$ in the water column (Bergquist and Blum, 2007). $\Delta^{199} \mathrm{Hg} / \Delta^{201} \mathrm{Hg}$ line regression is of $1.06 \pm 0.19(\mathrm{SE})$, intercept $=0.12 \pm 0.21(\mathrm{SE}), \mathrm{R}^{2}=0.70, \mathrm{p}=0.0001$. Highlighted circle symbols with error bars represent mean $\pm S D$ values for each tissue ( $n=3$, except livers $\mathrm{n}=2$ ). Whole individual data are included in SI (Table S5). 


\section{References}

Bergquist, B.A., Blum, J.D., 2007. Mass-dependent and -independent fractionation of $\mathrm{Hg}$ isotopes by photoreduction in aquatic systems. Science 318, 417-20. https://doi.org/10.1126/science. 1148050

Bolea-Fernandez, E., Rua-Ibarz, A., Krupp, E.M., Feldmann, J., Vanhaecke, F., 2019. Highprecision isotopic analysis sheds new light on mercury metabolism in long-finned pilot whales (Globicephala melas). Sci. Rep. 9, 1-10. https://doi.org/10.1038/s41598-019-43825$\mathrm{Z}$

Bridges, C.C., Zalups, R.K., 2010. Transport of inorganic mercury and methylmercury in target tissues and organs. J. Toxicol. Environ. Health. B. Crit. Rev. 13, 385-410. https://doi.org/10.1080/10937401003673750

Cipro, C.V.Z., Cherel, Y., Caurant, F., Miramand, P., Méndez-Fernandez, P., Bustamante, P., 2014. Trace elements in tissues of white-chinned petrels (Procellaria aequinoctialis) from Kerguelen waters, Southern Indian Ocean. Polar Biol. 37, 763-771. https://doi.org/10.1007/s00300-014-1476-Z

Clarkson, T.W., Magos, L., 2006. The toxicology of mercury and its chemical compounds. Crit. Rev. Toxicol. 36, 609-662. https://doi.org/10.1080/10408440600845619

Evers, D.C., Savoy, L.J., Desorbo, C.R., Yates, D.E., Hanson, W., Taylor, K.M., Siegel, L.S., Cooley, J.H., Bank, M.S., Major, A., Munney, K., Mower, B.F., Vogel, H.S., Schoch, N., Pokras, M., Goodale, M.W., Fair, J., 2008. Adverse effects from environmental mercury loads on breeding common loons. Ecotoxicology 17, 69-81. https://doi.org/10.1007/s10646-007-0168-7

Feng, C., Pedrero, Z., Gentès, S., Barre, J., Renedo, M., Tessier, E., Berail, S., Maury-Brachet, R., Mesmer-Dudons, N., Baudrimont, M., Legeay, A., Maurice, L., Gonzalez, P., Amouroux, D., 2015. Specific pathways of dietary methylmercury and inorganic mercury determined by mercury speciation and isotopic composition in zebrafish (Danio rerio). Environ. Sci. Technol. 49, 12984-12993. https://doi.org/10.1021/acs.est.5b03587

Kim, E.Y., Murakami, T., Saeki, K., Tatsukawa, R., 1996. Mercury levels and its chemical form in tissues and organs of seabirds. Arch. Environ. Contam. Toxicol. 30, 259-266. https://doi.org/10.1007/BF00215806

Li, M., Juang, C.A., Ewald, J.D., Yin, R., Mikkelsen, B., Krabbenhoft, D.P., Balcom, P.H., Dassuncao, C., Sunderland, E.M., 2020. Selenium and stable mercury isotopes provide new insights into mercury toxicokinetics in pilot whales. Sci. Total Environ. 710, 136325. https://doi.org/10.1016/j.scitotenv.2019.136325

Li, M., Sherman, L.S., Blum, J.D., Grandjean, P., Weihe, P., Sunderland, E.M., Shine, J.P., 2014. Assessing sources of human methylmercury exposure using stable mercury isotopes. Environ. Sci. Technol. 48, 8800-8806.

Masbou, J., Point, D., Sonke, J.E., Frappart, F., Perrot, V., Amouroux, D., Richard, P., Becker, P.R., 2015. Hg Stable Isotope Time Trend in Ringed Seals Registers Decreasing Sea Ice Cover in the Alaskan Arctic. Env. Sci Technol 49, 8977-8985. https://doi.org/10.1021/es5048446 
Masbou, J., Sonke, J.E., Amouroux, D., Guillou, G., Becker, P.R., Point, D., 2018. Hg-Stable Isotope Variations in Marine Top Predators of the Western Arctic Ocean. ACS Earth Sp. Chem. 0, null. https://doi.org/10.1021/acsearthspacechem.8b00017

Wagemann, R.U., Trebacz, E., Boila, G., Lockhart, W.L., 1998. Methylmercury and total mercury in tissues of arctic marine mammals. Sci. Total Environ. 218, 19-31.

Wang, R., Feng, X.-B., Wang, W.-X., 2013. In vivo mercury methylation and demethylation in freshwater tilapia quantified by mercury stable isotopes. Environ. Sci. Technol. 47, 794957. https://doi.org/10.1021/es3043774

Yamakawa, A., Takeuchi, A., Shibata, Y., Berail, S., Donard, O.F.X., 2016. Determination of Hg isotopic compositions in certified reference material NIES No. 13 Human Hair by cold vapor generation multi-collector inductively coupled plasma mass spectrometry. Accredit. Qual. Assur. 